\title{
Isoflavone glycosides: synthesis and evaluation as $\alpha$-glucosidase inhibitors
}

Guo Wei and Biao Yu*

State Key Laboratory of Bio-organic and Natural Products Chemistry, Shanghai Institute of Organic Chemistry, Chinese Academy of Sciences, Shanghai 200032, China.

*Corresponding author. Tel.: +86 21 54925132; fax: +86 2164166128

E-mail address: byu@mail.sioc.ac.cn

Keywords: $\alpha$-Glucosidase inhibitor; Isoflavone glycoside; A-76202; Synthesis; Suzuki-Miyaura coupling.

\begin{abstract}
Based on the structure of 4',8-dihydroxyisoflavon-7-yl $\alpha$-D-arabinofuranoside (namely A-76202, 1), a Rhodococcus metabolite showing potent inhibitory activities against the $\alpha$-glucosidases of rat liver microsome $\left(\mathrm{IC}_{50}=0.46 \mathrm{ng} / \mathrm{mL}\right), 26$ analogs each with minor variations at the sugar moiety, the isoflavone $\mathrm{A}$, and $\mathrm{B}$ rings, respectively, are readily synthesized. Notably, a new and efficient method is developed for the divergent synthesis of the B-ring congeners of the isoflavone glycosides using Suzuki-Miyaura coupling as the final step. Modifications at the sugar moiety and the isoflavone A ring significantly diminish the activity, while variations on the B ring are largely tolerated for retaining the potent $\alpha$-glucosidase inhibitory activity.
\end{abstract}

\section{Introduction}

The generation of glycoproteins involves the cotranslational transference of 
the tetradeca-oligosaccharide $\mathrm{Glc}_{3} \mathrm{Man}_{9} \mathrm{GlcNAc}_{2}$ from the dolichyl diphosphate to the $\mathrm{N}$-asparagine of the nascent protein, by the action of the oligosaccharyl-transferase in the lumen of the reticulum endoplasmatic membrane. ${ }^{[1]}$ Then the processing enzymes, $\alpha$-glucosidase I and II, cleave the Glc $(1 \rightarrow 2)$ Glc and Glc $(1 \rightarrow 3)$ Glc linkages in this $N$-linked oligosaccharide respectively, to liberate the three terminal glucose residues. ${ }^{[2]}$ This immature glycoprotein is further processed by the concomitant action of glycosidases and transferases to give specific glycoconjugates, which play fundamental roles in the biological processes, such as the immune response, intercellular recognition, cellular differentiation, the stability and solubility of proteins, and in pathological processes, such as inflammation and cancer. ${ }^{[3]}$ Tremendous efforts have been given to the development of glucosidase inhibitors which are of potentially usefulness for the treatment of diabetes, ${ }^{[4]}$ obesity, ${ }^{[5]}$ glycosphingolipid lysosomal storage disease, ${ }^{[6]}$ HIV infections, ${ }^{[7]}$ and tumors. ${ }^{[8]}$ The potent inhibitors with $\mathrm{IC}_{50}$ at $\mathrm{nM}$ level are largely structural mimics of the transition state of the hydrolyses of the glucosidic linkage. ${ }^{[9]}$ In this regard, 4',8-dihydroxyisoflavon-7-yl $\alpha$-D-arabinofuranoside (1) is an exception which shows potent inhibitory activity (against the $\alpha$-glucosidases of rat liver mcrosome) with an $\mathrm{IC}_{50}$ of $0.46 \mathrm{ng} / \mathrm{mL} .^{[10]}$ This isoflavone glycoside, named A-76202, was isolated by Takatsuki et al. in 1996 from Rhodococcus sp. SANK 61694. Shiozaki et al. have synthesized this compound along with several hexopyranoside analogs (2), and evaluated their $\alpha$-glucosidase inhibitory activities. ${ }^{[11]}$ However, these hexose analogs were found inactive. We have developed a general approach to the synthesis of flavone 7-O-glycosides, such as A-76202 (1). ${ }^{[12]}$ Here we report the synthesis of a series of the analogs of $\mathbf{1}$, each with minor variations at the sugar moiety, the isoflavone $\mathrm{A}$, and $\mathrm{B}$ rings, respectively, and the evaluation of their $\alpha$-glucosidase inhibitory activities. 


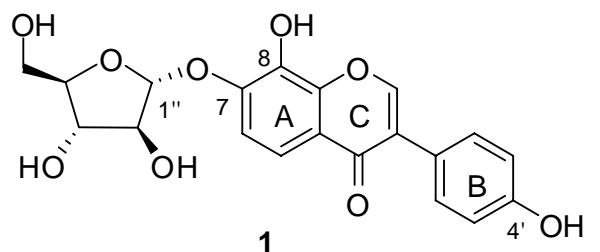<smiles>O=c1c(-c2ccc(O)cc2)coc2c(O)c(OC3OC(CO)C(O)C(O)C3O)ccc12</smiles>

Figure 1. A-76202 (1) and the hexose analogues (2) synthesized by Shiozaki et al.

\section{Results and Discussion}

\section{Synthesis}

Adopting modification of our previous method for the synthesis of flavone 7-O-glycosides, ${ }^{[12]}$ the desired 4',8-dihydroxyisoflavon-7-yl pentosides (9a-d) and the natural product $\mathbf{1}$ as well were readily prepared via glycosylation of the ready available $4^{\prime}, 8$-di-O-hexanoyl isoflavone derivative $\mathbf{8}^{[12]}$ with the corresponding peracetyl pentosyl trichloroacetimidates $3-7^{[13-17]}$ under the promotion of $\mathrm{BF}_{3} \cdot \mathrm{OEt}_{2}$ and subsequent removal of the acyl groups with $\mathrm{K}_{2} \mathrm{CO}_{3}$ in a mixed solvent of $\mathrm{MeOH} / \mathrm{THF} / \mathrm{H}_{2} \mathrm{O}$ (Scheme 1). The yields (over two steps) are only moderate (26\%-76\%); partial migration of the 8-O-hexanoyl group onto the neighboring $7-\mathrm{OH}$ under the glycosylation conditions was observed.

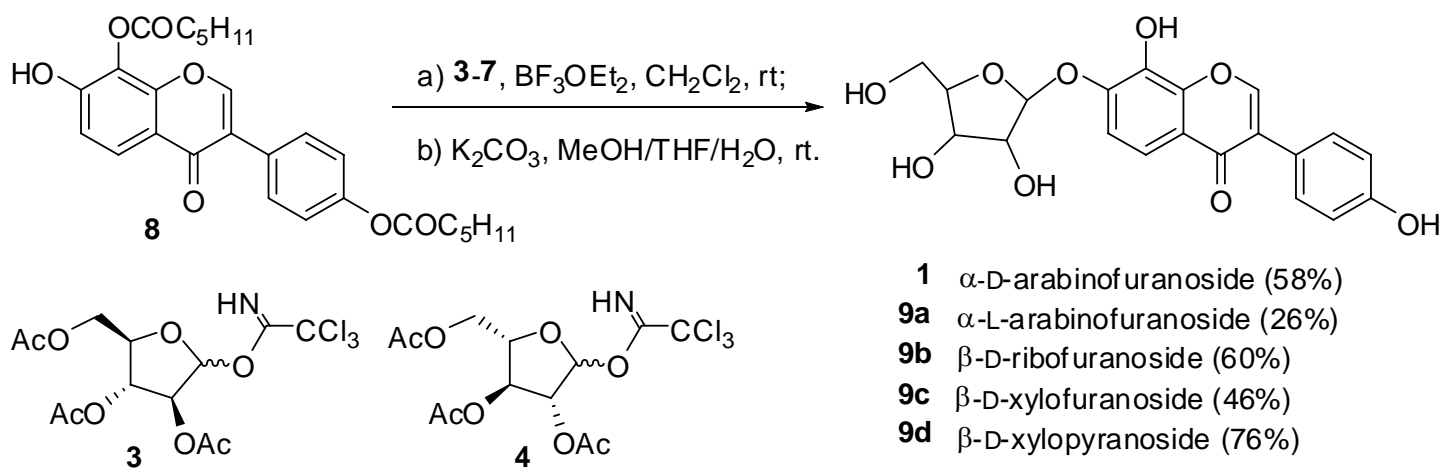<smiles>CC(=O)OC[C@H]1O[C@@H](OC(=N)C(Cl)(Cl)Cl)[C@H](OC(C)=O)[C@@H]1OC(C)(C)C</smiles><smiles>CC(=O)OC[C@H]1O[C@@H](OC(N)C(Cl)(Cl)Cl)[C@H](OC(C)=O)[C@@H]1OC(C)=O</smiles>

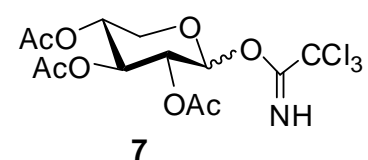


Scheme 1. Synthesis of the 4',8-dihydroxyisoflavon-7-yl pentosides $\mathbf{1}$ and 9a-d.

To synthesize the A and B ring congeners of A-76202 (1), a divergent approach by using Suzuki-Miyaura coupling ${ }^{[18]}$ of a 3-bromo-4H-chromen-7-yl $\alpha$-D-arabinofuranoside (i.e., 15 and 21) with a panel of the commercially available aryl boronic acids as the final step was envisioned. The required chromen-3-bromides 15 and 21 were prepared as shown in Schemes 2 and 3.

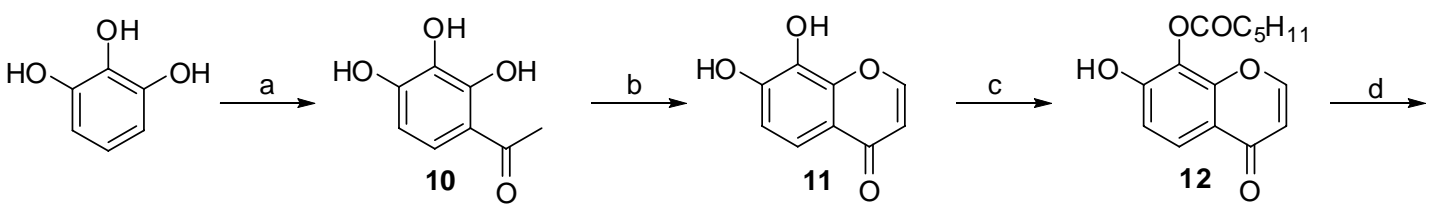

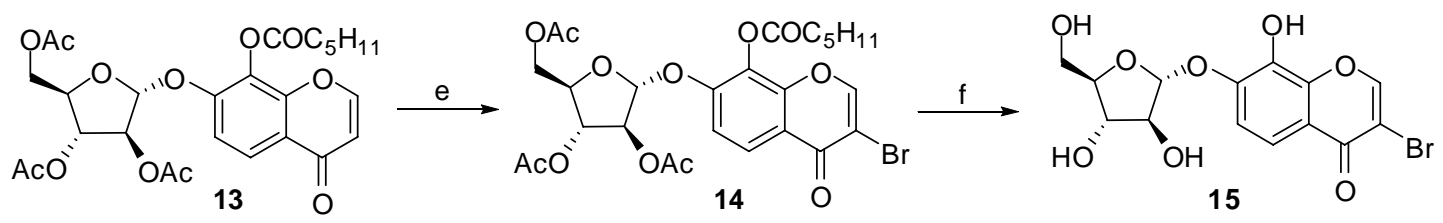

Scheme 2. Synthesis of 3-bromo-8-hydroxy-4-oxo-4H-chromen-7-yl a-D-arabinofuranoside 15. (a) $\mathrm{AcOH}_{3} \mathrm{BF}_{3} \cdot \mathrm{OEt}_{2}, 90 \sim 100^{\circ} \mathrm{C}, 4 \mathrm{~h}, 96 \%$. (b) $\mathrm{HC}(\mathrm{OEt})_{3}$, $70 \% \mathrm{HClO}_{4}, 85{ }^{\circ} \mathrm{C}, 12 \mathrm{~h}, 82 \%$. (c) i) $\mathrm{CH}_{3}\left(\mathrm{CH}_{2}\right)_{4} \mathrm{COCl}$, pyridine, $0{ }^{\circ} \mathrm{C}$-rt, $16 \mathrm{~h}$; ii) PhSH, imidazole, NMP, $0{ }^{\circ} \mathrm{C}-\mathrm{rt}, 3 \mathrm{~h}, 70 \%$. (d) $3, \mathrm{BF}_{3} \cdot \mathrm{OEt}_{2}, \mathrm{CH}_{2} \mathrm{Cl}_{2}, 4 \AA \mathrm{MS}, \mathrm{rt}, 62 \%$. (e) $\mathrm{PhI}(\mathrm{OAc})_{2}, \mathrm{TMSBr}, \mathrm{CH}_{2} \mathrm{Cl}_{2}$, pyridine, $0{ }^{\circ} \mathrm{C}$-rt, $67 \%$. f) $\mathrm{K}_{2} \mathrm{CO}_{3}, \mathrm{MeOH} / \mathrm{THF} / \mathrm{H}_{2} \mathrm{O}$ $(2: 1: 0.2), \mathrm{rt}, 77 \%$.

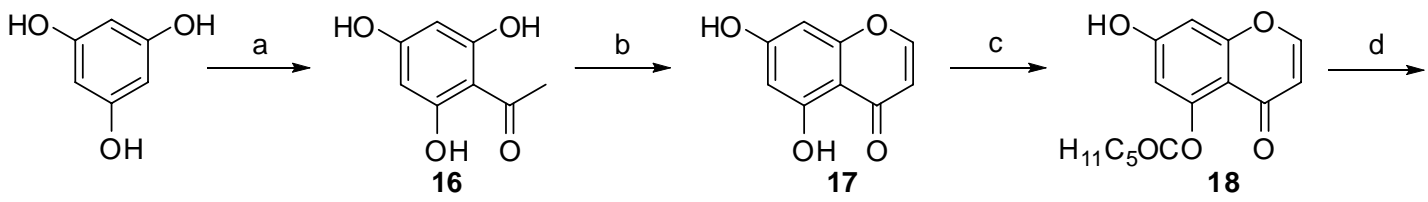

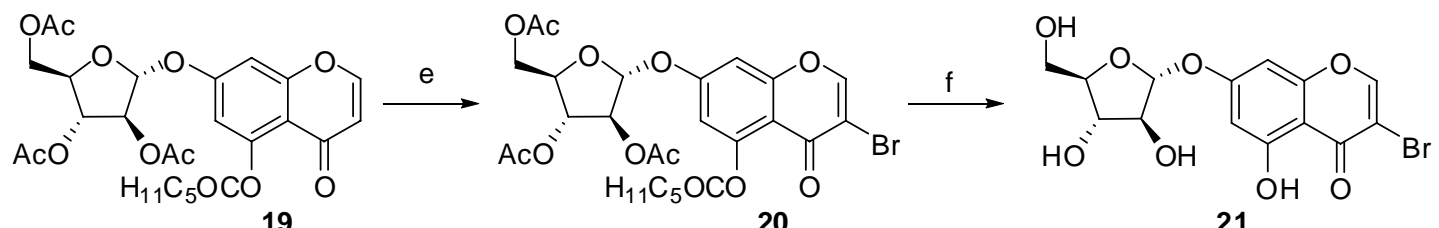


Scheme 3. Synthesis of 3-bromo-5-hydroxy-4-oxo-4H-chromen-7-yl

$\alpha$-D-arabinofuranoside 21. (a) $\mathrm{Ac}_{2} \mathrm{O}, \mathrm{BF}_{3} \cdot \mathrm{OEt}_{2}, \mathrm{rt}, 34 \mathrm{~h}$; (b) $\mathrm{MsCl}, \mathrm{DMF}, \mathrm{BF}_{3} \cdot \mathrm{OEt}_{2}$, $50^{\circ} \mathrm{C}, 4 \mathrm{~h}, 37 \%$. (c) i) $\mathrm{CH}_{3}\left(\mathrm{CH}_{2}\right)_{4} \mathrm{COCl}$, pyridine, $0{ }^{\circ} \mathrm{C}-\mathrm{rt}, 16 \mathrm{~h}$; ii) $\mathrm{PhSH}$, imidazole, NMP, $0{ }^{\circ} \mathrm{C}-\mathrm{rt}, 3$ h, 64\%. (d) 3, $\mathrm{BF}_{3} \cdot \mathrm{OEt}_{2}, \mathrm{CH}_{2} \mathrm{Cl}_{2}, 4 \AA \mathrm{MS}, \mathrm{rt}, 89 \%$. (e) $\mathrm{PhI}(\mathrm{OAc})_{2}$, TMSBr, $\mathrm{CH}_{2} \mathrm{Cl}_{2}$, pyridine, $0{ }^{\circ} \mathrm{C}-\mathrm{rt}, 63 \%$. (f) $\mathrm{K}_{2} \mathrm{CO}_{3}, \mathrm{MeOH} / \mathrm{THF} / \mathrm{H}_{2} \mathrm{O}$ (2:1:0.2), rt, $42 \%$.

Thus, acylation of pyrogallol with glacial acetic acid under the action of $\mathrm{BF}_{3} \cdot \mathrm{OEt}_{2}$ at $90 \sim 100^{\circ} \mathrm{C}$ provided ketone 10, which was treated with triethyl orthoformate in the presence of $70 \% \mathrm{HClO}_{4}$ to afford chromone 11 (Scheme 2). Selective protection of the 5-OH in diol 11 was achieved via 5,7-di-O-hexanoate formation and subsequent removal of the 7-O-acyl group, ${ }^{[12]}$ which is para to the electron-withdrawing pyrone carbonyl function, with $\mathrm{PhSH}$ and imidazole in $N$-methyl pyrolidinone (NMP) to give 12 (70\% for two steps). Glycosylation of phenol 12 with 2,3,5-tri-O-acetyl-D-arabinofuranosyl trichloroacetimidate (3) under the promotion of $\mathrm{BF}_{3} \cdot \mathrm{OEt}_{2}$ led to the $\alpha$-glycoside 13 in $62 \%$ yield. Bromination of compound 13 was achieved with $\mathrm{PhI}(\mathrm{OAc})_{2}$ and $\mathrm{TMSBr}$ at room temperature with pyridine as a base, ${ }^{[19]}$ affording chromone 3-bromide 14. Removal of the acyl protecting groups in $\mathbf{1 4}$ with $\mathrm{K}_{2} \mathrm{CO}_{3}$ in a mixed solvent of $\mathrm{MeOH} / \mathrm{THF} / \mathrm{H}_{2} \mathrm{O}$, to compromise the solubility of the reactants, provided the desired 7- $\alpha$-D-arabinofuranosyloxy-chromon-3-bromide 15.

Employing a similar procedure described above, the A ring isomer $\mathbf{2 1}$ was synthesized with phloroglucinol as the starting material (Scheme 3). Worth noting is that the glycosylation of the 5-O-hexanoyl-7-ol $\mathbf{1 8}$ with arabinofuranosyl 
trichloroacetimidate 3 gave the glycoside 19 in a much better $89 \%$ yield comparing to the glycosylation of 8-O-hexanoyl-7-ol 12 with imidate 3 (and the glycosylation of the isoflavone derivative 8 as well, Scheme 1) under similar conditions (62\%). The latter reaction suffered from the migration of the 8-O-hexanoyl group onto the neighboring 7-OH under the glycosylation conditions as mentioned.

Although Suzuki-Miyaura reaction has been widely used as one of the most efficient methods for C-C bond formation, ${ }^{[18]}$ in only few examples flavonoid iodides or $O$-triflates have been employed as the coupling partners. ${ }^{[20]}$ In fact, the instability of the $4 \mathrm{H}$-pyranones under basic conditions limited the choice of bases in the Suzuki-Miyaura coupling of bromides 15 and 21 with boronic acids. Under the optimized conditions with 2-(2,6-dimethoxybiphenyl)dicyclohexylphosphine (SPhos) as a ligand, as introduced by Buchwald et $\mathrm{al}^{[21]}$ in the presence of $\mathrm{Pd}(\mathrm{OAc})_{2}$ and $\mathrm{K}_{2} \mathrm{CO}_{3}$, coupling of bromide $\mathbf{1 5}$ with a variety of the aryl boronic acids provided the corresponding isoflavone glycosides 22a-n in moderate yields (Table 1). Reduction of the bromide and degradation of the chromone B ring are the major side reactions.

Table 1. Synthesis of the B-ring congeners (22) via Suzuki-Miyaura coupling of $\mathbf{1 5 .}$

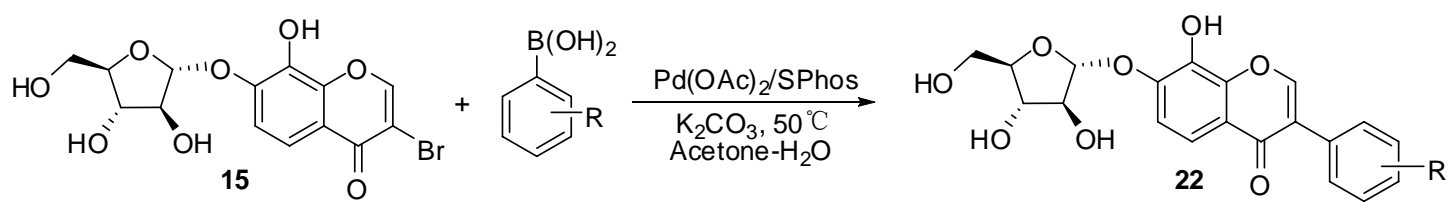

\begin{tabular}{ccc}
\hline Product & $\mathrm{R}$ & Yield $(\%)$ \\
\hline 22a & $\mathrm{H}$ & 65 \\
22b & $4-\mathrm{OMe}$ & 54 \\
22c & $2-\mathrm{OMe}$ & 50 \\
22d & $3-\mathrm{OMe}$ & 75 \\
22e & $4-\mathrm{Me}$ & 45 \\
22f & $2-\mathrm{Me}$ & 34
\end{tabular}




\begin{tabular}{ccc}
$\mathbf{2 2 g}$ & $3-\mathrm{Me}$ & 58 \\
$\mathbf{2 2 h}(\mathbf{1})$ & $4-\mathrm{OH}$ & 48 \\
$\mathbf{2 2 i}$ & $3-\mathrm{OH}$ & 35 \\
$\mathbf{2 2 j}$ & $4-\mathrm{F}$ & 31 \\
$\mathbf{2 2 k}$ & $4-\mathrm{NMe}_{2}$ & 36 \\
$\mathbf{2 2}$ & $4-\mathrm{NHBoc}$ & 39 \\
$\mathbf{2 2} \mathbf{m}$ & $4-\mathrm{CF}_{3}$ & 41 \\
$\mathbf{2 2 n}$ & $4-\mathrm{SiMe}_{3}$ & 30 \\
\hline
\end{tabular}

Under similar conditions, the couplings with chromon-3-bromide $\mathbf{2 1}$ gave lower yields of the desired product (Table 2), because chromone $\mathbf{2 1}$ was found more vulnerable to basic degradation than its region-isomer 15. An alternative procedure for this coupling was in the absence of ligand and with NaOAc as a base, but the coupling yields were even lower.

Table 2. Synthesis of the A,B-ring congeners (23) via Suzuki coupling of 21.

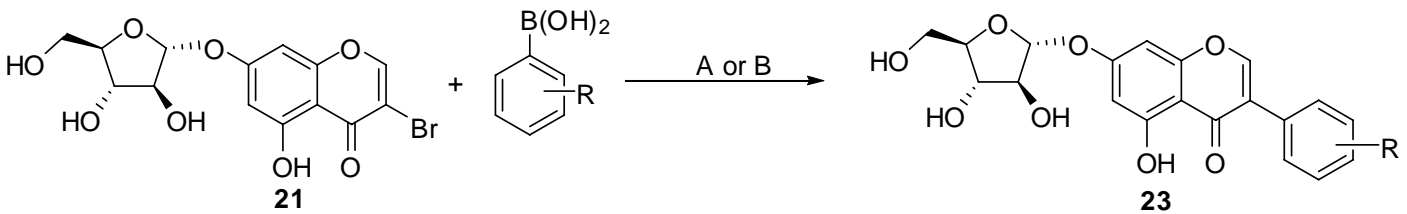

\begin{tabular}{|c|c|c|c|}
\hline Entry & $\mathrm{R}$ & Conditions & Yield (\%) \\
\hline \multirow{2}{*}{ 23a } & \multirow{2}{*}{$\mathrm{H}$} & $\mathrm{A}$ & 28 \\
\hline & & B & 16 \\
\hline $23 b$ & 4-OMe & A & 43 \\
\hline $23 c$ & 2-OMe & A & 39 \\
\hline $23 d$ & 3-OMe & A & 19 \\
\hline $23 e$ & 4-Me & B & 39 \\
\hline $23 f$ & 3-Me & A & 16 \\
\hline \multirow{2}{*}{$23 g$} & \multirow{2}{*}{$4-\mathrm{OH}$} & A & 39 \\
\hline & & $\mathrm{B}$ & 12 \\
\hline $23 \mathrm{~h}$ & $3-\mathrm{OH}$ & A & 35 \\
\hline
\end{tabular}

\section{Inhibitory activities against $\alpha$-glucosidases}

The synthetic natural product $\mathbf{1}$ exhibited potent inhibitory activity against the 
$\alpha$-glucosidases of rat liver microsome, with an $\mathrm{IC}_{50}=18 \mathrm{nM}$, that is comparable to the literature value of $14 \mathrm{nM}^{[11 \mathrm{~b}]}$ However, none of the stereoisomers (9a-d) showed remarkable activities at concentrations up to $10 \mu \mathrm{M}$. Gratifyingly, all the B ring analogs of 1 (22a-n) exhibited activities at $10 \mathrm{nM}$ concentration (Table 3 ). The 4-OH in the $\mathrm{B}$ ring of 1 could be replaced by $-\mathrm{OMe},-\mathrm{H},-\mathrm{F},-\mathrm{Me}$, and $-\mathrm{CF}_{3}$ without considerably affecting the activity. Their regio-isomers, i.e., the 3-OH, 2-OMe, 3-OMe, 2-Me, and 3-Me derivatives, were similarly potent. Especially, the 3-OMe and $4-\mathrm{NMe}_{2}$ derivatives (22d and 22I) were about 3-fold more potent that the 4'-OH natural product (1). However, the 5-OH (on the A ring) derivatives, which are regio-isomers of the above 8-OH isoflavone glycosides (22a-n) were 1000 times less potent inhibitiors. Worth of noting is that all these compounds, including the natural flavone glycoside 1, were found inert toward the $\alpha$-glucosidase from bakers yeast.

Table 3. Inhibitory activities of the isoflavone 7-O- $\alpha$-D-arabinofuranosides 22 and 23 against the $\alpha$-glucosidases of rat liver microsome.

\begin{tabular}{|c|c|c|}
\hline $\mathrm{R}$ & \multicolumn{2}{|c|}{ Compound $\left(\mathrm{IC}_{50}\right.$, in $\left.\mu \mathrm{M}\right)$} \\
\hline $\mathrm{H}$ & 22a $(0.040)$ & 23a (10) \\
\hline 4-OMe & $22 \mathbf{b}(0.022)$ & $\mathbf{2 3 b}(8)$ \\
\hline 2-OMe & $22 c(0.015)$ & $23 c(10)$ \\
\hline 3-OMe & 22d (0.006) & 23d (10) \\
\hline 4-Me & $22 \mathrm{e}(0.035)$ & 23e (7) \\
\hline 2-Me & $22 f(0.020)$ & - \\
\hline 3-Me & $22 \mathrm{~g}(0.050)$ & $23 f(5)$ \\
\hline
\end{tabular}




\begin{tabular}{|c|c|c|}
\hline 4-OH & $\mathbf{2 2 h} / \mathbf{1}(0.018)$ & $23 g(15)$ \\
\hline $3-\mathrm{OH}$ & $22 \mathbf{i}(0.017)$ & $\mathbf{2 3 h}(33 \%$ at 50$)$ \\
\hline $4-\mathrm{F}$ & $22 \mathbf{j}(0.015)$ & - \\
\hline $4-\mathrm{NMe}_{2}$ & $22 \mathbf{k}(0.008)$ & - \\
\hline 4-NHBoc & $221(0.020)$ & - \\
\hline $4-\mathrm{CF}_{3}$ & $22 \mathrm{~m}(0.030)$ & - \\
\hline $4-\mathrm{SiMe}_{3}$ & $22 \mathrm{n}(35 \%$ at 0.050$)$ & - \\
\hline
\end{tabular}

\section{Conclusions}

A concise approach to the synthesis of isoflavone glycosides has been developed, where the Suzuki-Miyaura coupling between glycosyloxy chromon-3-bromides (i.e., 15 and 21) and aryl boronic acids is employed as the final step. Although there remains room for increasing the coupling yields, and the glycosylation yields as well, the present method provides a quick and divergent access to this type of common natural products. Totally 26 isoflavone glycosides (9a-d, 22a-n, and 23a-h) have been readily synthesized, which are analogs of the potent $\alpha$-glucosidase inhibitor A-76202 with minor variations at the sugar moiety, the A, and B rings. Evaluation of the inhibitory activities of these compounds against the a-glucosidases of rat liver microsome has led to a preliminary and clear SAR (structure-activity relationship) conclusion: the stereochemistry of the sugar moiety (the $\alpha$-D-arabinofuranosyl unit) and the 8-hydroxyl group in the A ring are crucial to the activity, while variations on the $\mathrm{B}$ ring of the isoflavone 7-O-glycosides are largely tolerated to retain the potent $\alpha$-glucosidase inhibitory activities.

\section{Experimental}

General methods ${ }^{[12]}$ 


\section{General procedure for assay of the $\alpha$-glucosidase inhibitory activity}

$I C_{50}$ value was determined at $37^{\circ} \mathrm{C}$ in $0.1 \mathrm{M} \mathrm{K}_{2} \mathrm{HPO}_{4} / \mathrm{KH}_{2} \mathrm{PO}_{4}-0.15 \mathrm{M} \mathrm{KCl}$ buffer $(\mathrm{pH}$ 6.8), with $p$-nitrophenyl $\alpha$-D-glucopyranoside (purchased from Sigma Chemical Co.) as the substrate. Rat liver microsome fraction solubilized with $25 \%$ Triton X-100 was used as enzyme. The inhibitor ( $5 \mu \mathrm{L}$, in DMSO), diluted enzyme solution $(20 \mu \mathrm{L})$, and buffer solution $(105 \mu \mathrm{L})$ were added to a 96-well microtiter plate, and preincubated for $10 \mathrm{~min}$ at $37^{\circ} \mathrm{C}$. The enzymatic reaction was started by the addition of $20 \mu \mathrm{L}$ of the substrate solution $(20 \mathrm{mM})$. The absorption at $400 \mathrm{~nm}$ was measured immediately. The increase of absorption per min at $400 \mathrm{~nm}$ was taken as the relative rate for the hydrolysis of the substrate. The increase was linear during all measurements $(30 \mathrm{~min}) . I C_{50}$ values were determined by plotting the relative rate of the substrate hydrolysis vs. the inhibitor concentration. The inhibitor concentration corresponding to half of the relative rate measured in the absence of the inhibitor gave the appropriate $I C_{50}$ value. All the experiments were carried out in triplicate.

\section{Synthesis of 4',8-dihydroxyisoflavon-7-yl pentoses (1 and 9a-d)}

General procedure: $\mathrm{BF}_{3} \cdot \mathrm{OEt}_{2}\left(0.1 \mathrm{M}\right.$ in $\left.\mathrm{CH}_{2} \mathrm{Cl}_{2}, 0.4 \mathrm{~mL}\right)$ was added slowly to a solution of $\mathbf{8}(100 \mathrm{mg}, 0.214 \mathrm{mmol})$ and glycosyl trichloroacetimidate (250 mg, 0.612 mmol $)$ in dried $\mathrm{CH}_{2} \mathrm{Cl}_{2}(8 \mathrm{~mL})$ in the presence of newly activated $4 \AA$ molecular sieves at $0{ }^{\circ} \mathrm{C}$. The mixture was allowed to warm up to $\mathrm{rt}$ and stirred until TLC indicated the completion of the reaction. The solid in the mixture was filtered off by passing it through a celite pad and the filtrate was condensed in vacuo. The residue was dissolved in $\mathrm{MeOH} / \mathrm{THF} / \mathrm{H}_{2} \mathrm{O}(2: 1: 0.2,5 \mathrm{~mL})$ and $\mathrm{K}_{2} \mathrm{CO}_{3}(119 \mathrm{mg}, 0.856$ mmol) was added. The mixture was stirred at rt until TLC indicated the completion of the reaction. Dowex-50 $\left(\mathrm{H}^{+}\right)$resin was used to neutralize the reaction mixture. The solution was filtered, and the filtrate was concentrated. The residue was purified by 
silica gel column chromatography $\left(\mathrm{CH}_{2} \mathrm{Cl}_{2} / \mathrm{MeOH}, 10: 1\right)$ to yield $\mathbf{1}$ or 9 as a white solid.

4',8-Dihydroxyisoflavon-7-yl $\alpha$-D-arabinofuranoside (1, A-76202): Yield $=58 \%$. $\mathrm{R}_{f}$ $0.24\left(\mathrm{CH}_{2} \mathrm{Cl}_{2}: \mathrm{MeOH}=10: 1\right) ;{ }^{1} \mathrm{H}$ NMR $\left(300 \mathrm{MHz}, \mathrm{CD}_{3} \mathrm{OD}\right): \delta=8.22(\mathrm{~s}, 1 \mathrm{H}), 7.64$ $(\mathrm{d}, J=9.0 \mathrm{~Hz}, 1 \mathrm{H}), 7.37(\mathrm{~d}, J=8.7 \mathrm{~Hz}, 2 \mathrm{H}), 7.31(\mathrm{~d}, J=9.0 \mathrm{~Hz}, 1 \mathrm{H}), 6.84(\mathrm{~d}, J=$ $8.7 \mathrm{~Hz}, 2 \mathrm{H}), 5.74(\mathrm{~s}, 1 \mathrm{H}), 4.37(\mathrm{~d}, J=1.5 \mathrm{~Hz}, 1 \mathrm{H}), 4.16(\mathrm{dd}, J=8.7 \mathrm{~Hz}, 4.5 \mathrm{~Hz}, 1$ H), $4.07(\mathrm{~m}, 1 \mathrm{H}), 3.74(\mathrm{dd}, J=11.7 \mathrm{~Hz}, 3.6 \mathrm{~Hz}, 1 \mathrm{H}), 3.69(\mathrm{dd}, J=11.7 \mathrm{~Hz}, 5.1 \mathrm{~Hz}, 1$ $\mathrm{H}) ;{ }^{13} \mathrm{C}$ NMR (75 MHz, $\left.\mathrm{CD}_{3} \mathrm{OD}\right): \delta=178.5,159.1,157.7,154.6,153.2,131.8,126.2$, $124.4,123.1,119.3,116.6,116.3,110.0,90.1,82.4,79.0,63.5$.

4',8-Dihydroxyisoflavon-7-yl $\boldsymbol{\alpha}$-L-arabinofuranoside (9a): Yield $=26 \% . \mathrm{R}_{f} 0.38$ $\left(\mathrm{CH}_{2} \mathrm{Cl}_{2}: \mathrm{MeOH}=10: 1\right) ;[\alpha]_{\mathrm{D}}^{22}=-106.2(c$ 0.56, MeOH$) ;{ }^{1} \mathrm{H}$ NMR $(300 \mathrm{MHz}$, $\left.\mathrm{CD}_{3} \mathrm{OD}\right): \delta=8.21(\mathrm{~s}, 1 \mathrm{H}), 7.85(\mathrm{~d}, J=9.0 \mathrm{~Hz}, 1 \mathrm{H}), 7.37(\mathrm{~d}, J=8.7 \mathrm{~Hz}, 2 \mathrm{H}), 7.00(\mathrm{~d}$, $J=9.0 \mathrm{~Hz}, 1 \mathrm{H}), 6.84(\mathrm{~d}, J=8.7 \mathrm{~Hz}, 2 \mathrm{H}), 5.90(\mathrm{~s}, 1 \mathrm{H}), 4.40(\mathrm{~s}, 1 \mathrm{H}), 4.30(\mathrm{dd}, J=$ $7.8 \mathrm{~Hz}, 4.5 \mathrm{~Hz}, 1 \mathrm{H}), 4.10$ (br s, $1 \mathrm{H}), 3.67-3.62$ (m, $2 \mathrm{H})$; ESI-MS (m/z): $403.1(\mathrm{M}+$ $\mathrm{H}^{+}$); HRMS (ESI) calcd for $\mathrm{C}_{20} \mathrm{H}_{19} \mathrm{O}_{9}{ }^{+}$403.1024, Found: 403.1024 .

4',8-Dihydroxyisoflavon-7-yl $\beta$-D-ribofuranoside (9b): Yield $=60 \% . \quad \mathrm{R}_{f} \quad 0.14$ $\left(\mathrm{CH}_{2} \mathrm{Cl}_{2}: \mathrm{MeOH}=10: 1\right) ;[\alpha]_{\mathrm{D}}{ }^{23}=-107.6($ c $0.24, \mathrm{MeOH}) ;{ }^{1} \mathrm{H}$ NMR $(300 \mathrm{MHz}$, DMSO-d $\left._{6}\right): \delta=9.59($ br s, $1 \mathrm{H}), 8.41(\mathrm{~s}, 1 \mathrm{H}), 7.55(\mathrm{~d}, J=9.0 \mathrm{~Hz}, 1 \mathrm{H}), 7.41(\mathrm{~d}, J=$ 8.7 Hz, $2 \mathrm{H}), 7.24$ (d, J = 9.0 Hz, $1 \mathrm{H}), 6.83(\mathrm{~d}, J=8.7 \mathrm{~Hz}, 2 \mathrm{H}), 5.52(\mathrm{~s}, 1 \mathrm{H}), 5.05$ $(\mathrm{d}, J=6.0 \mathrm{~Hz}, 1 \mathrm{H}), 4.30-4.10(\mathrm{~m}, 2 \mathrm{H}), 3.94(\mathrm{br} \mathrm{s}, 1 \mathrm{H}), 3.61(\mathrm{dd}, J=12.0 \mathrm{~Hz}, 1.8 \mathrm{~Hz}$, $1 \mathrm{H}), 3.44(\mathrm{dd}, J=12.0 \mathrm{~Hz}, 6.0 \mathrm{~Hz}, 1 \mathrm{H}) ;{ }^{13} \mathrm{C} \mathrm{NMR}\left(75 \mathrm{MHz}, \mathrm{DMSO}-\mathrm{d}_{6}\right): \delta=175.4$, $157.4,153.4,148.1,146.3,136.4,130.4,123.5,122.7,120.0,115.3,115.2,115.16$, 115.10, 107.2, 84.9, 74.7, 70.2, 62.2; ESI-MS $(\mathrm{m} / \mathrm{z}): 403.2\left(\mathrm{M}+\mathrm{H}^{+}\right)$, HRMS (ESI) calcd for $\mathrm{C}_{20} \mathrm{H}_{19} \mathrm{O}_{9}{ }^{+}$403.1024, Found: 403.1023 .

4',8-Dihydroxyisoflavon-7-yl $\beta$-D-xylofuranoside (9c): Yield $=46 \% . \quad \mathrm{R}_{f} \quad 0.20$ 
$\left(\mathrm{CH}_{2} \mathrm{Cl}_{2}: \mathrm{MeOH}=10: 1\right) ;[\alpha]_{\mathrm{D}}{ }^{22}=-100.2($ c $0.21, \mathrm{MeOH}) ;{ }^{1} \mathrm{H}$ NMR $(300 \mathrm{MHz}$, DMSO-d $\left._{6}\right): \delta=9.45($ br s, $1 \mathrm{H}), 8.38(\mathrm{~s}, 1 \mathrm{H}), 7.55(\mathrm{~d}, J=9.0 \mathrm{~Hz}, 1 \mathrm{H}), 7.41(\mathrm{~d}, J=$ $8.4 \mathrm{~Hz}, 2 \mathrm{H}), 7.28$ (d, J=9.0 Hz, $1 \mathrm{H}), 6.82$ (d, J=8.4 Hz, $2 \mathrm{H}), 5.57$ (s, $1 \mathrm{H}), 4.31$ (s, $1 \mathrm{H}), 4.21(\mathrm{dd}, J=11.1,4.8 \mathrm{~Hz}, 1 \mathrm{H}), 4.07(\mathrm{dd}, J=4.5,1.5 \mathrm{~Hz}, 1 \mathrm{H}), 3.70(\mathrm{dd}, J=$ $11.7,4.8 \mathrm{~Hz}, 1 \mathrm{H}), 3.53(\mathrm{dd}, J=11.7,6.6 \mathrm{~Hz}, 1 \mathrm{H}) ;{ }^{13} \mathrm{C}$ NMR $\left(75 \mathrm{MHz}, \mathrm{DMSO}-\mathrm{d}_{6}\right): \delta$ $=175.2,157.2,153.1,147.2,145.9,137.3,130.1,123.4,122.6,120.1,115.6,115.0$, 107.7, 84.6, 80.3, 75.0, 60.1; ESI-MS (m/z): $401.3\left(\mathrm{M}-\mathrm{H}^{+}\right)$; HRMS (ESI) calcd for $\mathrm{C}_{20} \mathrm{H}_{19} \mathrm{O}_{9}^{+}$403.1024, Found: 403.1023.

4',8-Dihydroxyisoflavon-7-yl $\beta$-D-xylopyranoside (9d): Yield: 76\%. $\mathrm{R}_{f} 0.20$ (DCM : $\mathrm{MeOH}=10: 1) ;[\alpha]_{\mathrm{D}}{ }^{21}=-33.8(c 0.29, \mathrm{MeOH}) ;{ }^{1} \mathrm{H} \mathrm{NMR} \quad\left(300 \mathrm{MHz}, \mathrm{CD}_{3} \mathrm{OD}\right) \delta$ $=8.21(\mathrm{~s}, 1 \mathrm{H}), 7.63(\mathrm{~d}, J=8.7 \mathrm{~Hz}, 1 \mathrm{H}), 7.37(\mathrm{~d}, J=7.8 \mathrm{~Hz}, 2 \mathrm{H}), 7.25(\mathrm{~d}, J=8.7 \mathrm{~Hz}$, $1 \mathrm{H}), 6.84(\mathrm{~d}, J=7.8 \mathrm{~Hz}, 2 \mathrm{H}), 4.96(\mathrm{~d}, J=7.8 \mathrm{~Hz}, 1 \mathrm{H}), 3.90(\mathrm{dd}, J=11.1 \mathrm{~Hz}, 4.8 \mathrm{~Hz}$, $1 \mathrm{H}), 3.60-3.36(\mathrm{~m}, 4 \mathrm{H}) ;{ }^{13} \mathrm{C} \mathrm{NMR}\left(75 \mathrm{MHz}, \mathrm{CD}_{3} \mathrm{OD}\right) \delta=178.7,159.0,155.2$, $150.2,148.3,137.6,131.7,126.0,124.4,121.8,117.0,116.5,115.8,104.2,77.5,74.8$ 71.2, 67.3; ESI-MS (m/z): $401.1\left(\mathrm{M}-\mathrm{H}^{+}\right)$; HRMS (ESI) calcd for $\mathrm{C}_{20} \mathrm{H}_{18} \mathrm{O}_{9} \mathrm{Na}^{+}$ 425.0843, Found: 425.0813.

Synthesis of 3-bromo-8-hydroxy-4-oxo-4H-chromen-7-yl a-D-arabinofuranoside (15)

1-(2,3,4-Trihydroxyphenyl)ethanone (10): A solution of pyrogallol (12.61 g, 100 mmol) and glacial acetic acid $(64 \mathrm{~mL}, 110.9 \mathrm{mmol})$ in $\mathrm{BF}_{3} \cdot \mathrm{OEt}_{2}(37 \mathrm{~mL})$ was heated at $90-100{ }^{\circ} \mathrm{C}$ for $4 \mathrm{~h}$ in the protection of argon, cooled, and then poured into $10 \%$ NaOAc $(600 \mathrm{~mL})$, and stirred overnight. The dark solution was extracted with ether (3 $\times 300 \mathrm{~mL}$ ). The organic layer was washed with saturated $\mathrm{NaCl}$ and dried with anhydrous $\mathrm{Na}_{2} \mathrm{SO}_{4}$. Removal of the solvent gave $\mathbf{1 0}(16.1 \mathrm{~g}, 96 \%)$ as a yellow solid. $\mathrm{R}_{f} 0.69\left(\mathrm{CH}_{2} \mathrm{Cl}_{2}: \mathrm{MeOH}=10: 1\right)$. 
7,8-Dihydroxy-4H-chromen-4-one (11): Compound 10 (10.0g, $59.47 \mathrm{mmol})$ was suspended in ethyl orthoformate $(50 \mathrm{~mL}, 300 \mathrm{mmol})$ and was treated with $70 \% \mathrm{HClO}_{4}$ (6 mL) slowly. The mixture was heated on an oil bath at $85^{\circ} \mathrm{C}$ for $12 \mathrm{~h}$, and was then cooled, and $200 \mathrm{~mL}$ ether was added. The precipitate was filtered off, washed with water, and dried, giving crude $11(8.72 \mathrm{~g}, 82 \%)$ as yellow solid. $\mathrm{R}_{f} 0.45\left(\mathrm{CH}_{2} \mathrm{Cl}_{2}\right.$ : $\mathrm{MeOH}=10: 1)$.

7-Hydroxy-4-oxo-4H-chromen-8-yl hexanoate (12): Hexanoyl chloride (27 mL, $195.6 \mathrm{mmol})$ was added to a stirring solution of $\mathbf{1 1}(6.8 \mathrm{~g}, 38.2 \mathrm{mmol})$ in pyridine at 0 ${ }^{\circ} \mathrm{C}$, the mixture was allowed to warm up to rt. After stirring for an additional $16 \mathrm{~h}$, the solution was diluted with $\mathrm{CH}_{2} \mathrm{Cl}_{2}$, and then was washed with $1 \mathrm{~N}$ aq. $\mathrm{HCl}$ and saturated $\mathrm{NaCl}$. The organic layer was dried with anhydrous $\mathrm{Na}_{2} \mathrm{SO}_{4}$, and then concentrated in vacuum. The resulting residue was dissolved into dried NMP (60 mL). Imidazole ( $1.10 \mathrm{~g}, 15.84 \mathrm{mmol})$ was added and the solution was cooled to $0{ }^{\circ} \mathrm{C}$ by an ice-water bath, followed by the addition of $\mathrm{PhSH}(5.8 \mathrm{~mL}, 56.94 \mathrm{mmol})$. The reaction mixture was stirred and allowed to warm up to rt naturally. When TLC indicated the completion of the reaction, $\mathrm{CH}_{2} \mathrm{Cl}_{2}(300 \mathrm{~mL})$ was added, the resulting mixture was washed with $1 \mathrm{~N}$ aq. $\mathrm{HCl}$, water, and saturated $\mathrm{NaCl}$ sequentially. The organic layer was dried with anhydrous $\mathrm{Na}_{2} \mathrm{SO}_{4}$, and concentrated in vacuum. The residue was purified by silica gel column chromatography (petroleum ether : EtOAc $=2: 1$ ) to yield 12 as a yellow solid (7.64 g, 70\% for two steps). $\mathrm{R}_{f} 0.17$ (petroleum ether : EtOAc $=2: 1) ;{ }^{1} \mathrm{H}$ NMR $\left(300 \mathrm{MHz}, \mathrm{CDCl}_{3}\right): \delta=8.28($ br s, $1 \mathrm{H}), 7.98(\mathrm{~d}, J=9.0 \mathrm{~Hz}$, $1 \mathrm{H}), 7.79(\mathrm{~d}, J=5.7 \mathrm{~Hz}, 1 \mathrm{H}), 7.11(\mathrm{~d}, J=9.0 \mathrm{~Hz}, 1 \mathrm{H}), 6.32(\mathrm{~d}, J=5.7 \mathrm{~Hz}, 1 \mathrm{H})$, $2.71(\mathrm{t}, J=7.5 \mathrm{~Hz}, 2 \mathrm{H}), 1.82(\mathrm{p}, J=7.2 \mathrm{~Hz}, 2 \mathrm{H}), 1.48-1.35(\mathrm{~m}, 4 \mathrm{H}), 0.93(\mathrm{t}, J=6.9$ $\mathrm{Hz}, 3 \mathrm{H})$. 
furanoside (13): A solution of $\mathbf{1 2}(7.64 \mathrm{~g}, 27.65 \mathrm{mmol})$ and glycosyl imidate $\mathbf{3}$ (17.86 g, $42.46 \mathrm{mmol})$ in dried $\mathrm{CH}_{2} \mathrm{Cl}_{2}(200 \mathrm{~mL})$ was treated with newly activated $4 \AA \mathrm{MS}$ and stirred at $\mathrm{rt}$ for $15 \mathrm{~min} . \mathrm{BF}_{3} \cdot \mathrm{OEt}_{2}(2.8 \mathrm{~mL}, 2.80 \mathrm{mmol})$ was added dropwise to the solution at $0{ }^{\circ} \mathrm{C}$, and the reaction mixture was stirred at $\mathrm{rt}$ for $3 \mathrm{~h}$, and then $\mathrm{Et}_{3} \mathrm{~N}(5 \mathrm{~mL})$ was added to quench the reaction. The solid was filtered off by passing the reaction through a celite pad and the solvent was removed in vacuum. The residue was purified by silica gel column chromatography (petroleum ether : EtOAc $=2: 1$ ) to yield $\mathbf{1 3}$ as a yellows syrup $(9.1 \mathrm{~g}, 62 \%) . \mathrm{R}_{f} 0.53$ (petroleum : EtOAc $\left.=1: 1\right) ;{ }^{1} \mathrm{H}$ NMR $(300 \mathrm{MHz}$, $\left.\mathrm{CDCl}_{3}\right): \delta=8.05(\mathrm{~d}, J=9.0 \mathrm{~Hz}, 1 \mathrm{H}), 7.78(\mathrm{~d}, J=6.3 \mathrm{~Hz}, 1 \mathrm{H}), 7.31(\mathrm{~d}, J=9.0 \mathrm{~Hz}, 1$ H), $6.30(\mathrm{~d}, J=6.3 \mathrm{~Hz}, 1 \mathrm{H}), 5.79(\mathrm{~s}, 1 \mathrm{H}), 5.38(\mathrm{~s}, 1 \mathrm{H}), 5.11$ (br s, $1 \mathrm{H}), 4.47-4.35$ (m, $2 \mathrm{H}), 4.28(\mathrm{dd}, J=11.7 \mathrm{~Hz}, 4.5 \mathrm{~Hz}, 1 \mathrm{H}), 2.68$ (t, $J=7.8 \mathrm{~Hz}, 2 \mathrm{H}), 2.16(\mathrm{~s}, 3 \mathrm{H})$, $2.14(\mathrm{~s}, 3 \mathrm{H}), 2.11(\mathrm{~s}, 3 \mathrm{H}), 1.84(\mathrm{q}, J=7.5 \mathrm{~Hz}, 2 \mathrm{H}), 1.51-1.30(\mathrm{~m}, 4 \mathrm{H}), 0.96(\mathrm{t}, J=$ $6.6 \mathrm{~Hz}, 3 \mathrm{H}) ;{ }^{13} \mathrm{C} \mathrm{NMR}\left(75 \mathrm{MHz}, \mathrm{CDCl}_{3}\right): \delta=176.4,170.5,170.4,169.9,169.4$, $154.8,152.0,149.9,128.8,123.6,120.7,113.8,113.0,104.5,82.0,81.1,76.7,62.7$, 33.7, 31.2, 24.6, 22.2, 20.7, 20.6, 13.9; ESI-MS (m/z): $535.3\left(\mathrm{M}+\mathrm{H}^{+}\right), 557.3(\mathrm{M}+$ $\mathrm{Na}^{+}$); HRMS (MALDI) calcd for $\mathrm{C}_{26} \mathrm{H}_{30} \mathrm{O}_{12} \mathrm{Na}^{+}$557.1630, Found 557.1638.

\section{3-Bromo-8-(hexanoyloxy)-4-0xo-4H-chromen-7-yl}

2,3,5-tri-O-acetyl-a-D-arabinofuranoside (14): TMSBr (8.6 mL, $64.96 \mathrm{mmol})$ was added slowly to a solution of $\mathrm{PhI}(\mathrm{OAc})_{2}(10.6 \mathrm{~g}, 32.71 \mathrm{mmol})$ in dry $\mathrm{CH}_{2} \mathrm{Cl}_{2}(50 \mathrm{~mL})$ at $0{ }^{\circ} \mathrm{C}$, and the solution was stirred in an ice-bath for $45 \mathrm{~min}$ before the addition of $\mathbf{1 3}$ (5.8 g, $10.85 \mathrm{mmol})$ in $\mathrm{CH}_{2} \mathrm{Cl}_{2}(25 \mathrm{~mL})$. The ice-bath was removed and the reaction mixture was allowed to warm up to $\mathrm{rt}$ and stayed $2 \mathrm{~h}$. Pyridine $(5.7 \mathrm{~mL}, 66.47 \mathrm{mmol})$ was then added, and the stirring was continued for an additional $1 \mathrm{~h}$. The resulting mixture was diluted with $\mathrm{CH}_{2} \mathrm{Cl}_{2}$, and washed with saturated $\mathrm{Na}_{2} \mathrm{~S}_{2} \mathrm{O}_{3}$ and saturated $\mathrm{NaCl}$. The organic layer was dried with anhydrous $\mathrm{Na}_{2} \mathrm{SO}_{4}$, and concentrated in 
vacuum. The residue was purified by silica gel column chromatography (petroleum ether : EtOAc $=3: 1$ to $5: 2)$ to yield 14 as a yellow syrup $(4.5 \mathrm{~g}, 67 \%)$. $\mathrm{R}_{f} 0.85$ (petroleum ether : EtOAc $=1: 1) ;{ }^{1} \mathrm{H}$ NMR $\left(300 \mathrm{MHz}, \mathrm{CDCl}_{3}\right): \delta=8.15(\mathrm{~s}, 1 \mathrm{H})$, $8.11(\mathrm{~d}, J=9.0 \mathrm{~Hz}, 1 \mathrm{H}), 7.35(\mathrm{~d}, J=9.0 \mathrm{~Hz}, 1 \mathrm{H}), 5.80(\mathrm{~s}, 1 \mathrm{H}), 5.38(\mathrm{~s}, 1 \mathrm{H}), 5.12(\mathrm{~d}$, $J=3.6 \mathrm{~Hz}, 1 \mathrm{H}), 4.47-4.36(\mathrm{~m}, 2 \mathrm{H}), 4.28(\mathrm{dd}, J=11.1 \mathrm{~Hz}, 4.5 \mathrm{~Hz}, 1 \mathrm{H}), 2.68(\mathrm{t}, J=$ $7.5 \mathrm{~Hz}, 2 \mathrm{H}), 2.16(\mathrm{~s}, 3 \mathrm{H}), 2.14(\mathrm{~s}, 3 \mathrm{H}), 2.11(\mathrm{~s}, 3 \mathrm{H}), 1.83$ (q, J = $7.2 \mathrm{~Hz}, 2 \mathrm{H})$, $1.48-1.35(\mathrm{~m}, 4 \mathrm{H}), 0.96(\mathrm{t}, J=6.6 \mathrm{~Hz}, 3 \mathrm{H}) ;{ }^{13} \mathrm{C} \mathrm{NMR}\left(75 \mathrm{MHz}, \mathrm{CDCl}_{3}\right): \delta=171.2$, $170.4,170.38,169.9,169.4,153.2,152.3,149.6,128.6,124.2,118.8,114.5,110.9$, 104.5, 82.2, 81.1, 76.7, 62.7, 33.7, 31.2, 24.6, 22.2, 20.7, 20.62, 20.60, 13.9; ESI-MS $(\mathrm{m} / \mathrm{z}): 613.1\left(\mathrm{M}+\mathrm{H}^{+}\right), 635.2\left(\mathrm{M}+\mathrm{Na}^{+}\right)$; HRMS (MALDI) calcd for $\mathrm{C}_{26} \mathrm{H}_{29} \mathrm{O}_{12} \mathrm{BrNa}^{+}$ 635.0735, Found: 635.0721.

3-Bromo-8-hydroxy-4-oxo-4H-chromen-7-yl $\alpha$-D-arabinofuranoside (15): The chromone derivative $14(585 \mathrm{mg}, 0.954 \mathrm{mmol})$ in $\mathrm{MeOH} / \mathrm{THF} / \mathrm{H}_{2} \mathrm{O}(2: 1: 0.2,50 \mathrm{~mL})$ was treated with $\mathrm{K}_{2} \mathrm{CO}_{3}(527 \mathrm{mg}, 3.82 \mathrm{mmol})$ at $\mathrm{rt}$ for $10 \mathrm{~h}$. TLC indicated the completion of the reaction. Dowex-50 $\left(\mathrm{H}^{+}\right)$was added to neutralize the mixture. The solvent was removed in vacuum. Flash chromatography of the residue on silica gel yielded 15 as a yellow solid $(287 \mathrm{mg}, 77 \%) . \mathrm{R}_{f} 0.41\left(\mathrm{CH}_{2} \mathrm{Cl}_{2}: \mathrm{MeOH}=10: 1\right) ;[\alpha]_{\mathrm{D}}{ }^{24}$ $=74.7$ (c 0.20, MeOH); ${ }^{1} \mathrm{H}$ NMR $\left(300 \mathrm{MHz}, \mathrm{CD}_{3} \mathrm{OD}\right): \delta=8.57(\mathrm{~s}, 1 \mathrm{H}), 7.56(\mathrm{~d}, J=$ $9.0 \mathrm{~Hz}, 1 \mathrm{H}), 7.33$ (d, $J=9.0 \mathrm{~Hz}, 1 \mathrm{H}), 5.72(\mathrm{~s}, 1 \mathrm{H}), 4.36$ (d, $J=2.1 \mathrm{~Hz}, 1 \mathrm{H}), 4.13$ (dd, $J=9.0 \mathrm{~Hz}, 4.5 \mathrm{~Hz}, 1 \mathrm{H}), 4.08(\mathrm{~m}, 1 \mathrm{H}), 3.75(\mathrm{dd}, J=11.7 \mathrm{~Hz}, 3.6 \mathrm{~Hz}, 1 \mathrm{H}), 3.70$ (dd, $J=11.7 \mathrm{~Hz}, 5.1 \mathrm{~Hz}, 1 \mathrm{H}) ; \operatorname{ESI}-\mathrm{MS}(\mathrm{m} / \mathrm{z}): 410.8\left(\mathrm{M}+\mathrm{Na}^{+}\right)$.

Synthesis of 3-Bromo-5-hydroxy-4-oxo-4H-chromen-7-yl $\alpha$-D-arabinofuranoside (21)

1-(2,4,6-Trihydroxyphenyl)ethanone (16): A solution of phloroglucinol (25.0 g, 198 
mmol) and $\mathrm{Ac}_{2} \mathrm{O}(190 \mathrm{~mL}, 199.5 \mathrm{mmol})$ in $\mathrm{BF}_{3} \cdot \mathrm{OEt}_{2}(75 \mathrm{~mL})$ was stirred at $\mathrm{rt}$ for $34 \mathrm{~h}$, before it was poured into $10 \% \mathrm{NaOAc}(700 \mathrm{~mL})$ and stirred overnight. The precipitate was filtered off, washed with water and dried to give the crude $16(24 \mathrm{~g})$ as a yellow solid. $\mathrm{R}_{f} 0.74\left(\mathrm{CH}_{2} \mathrm{Cl}_{2}: \mathrm{MeOH}=5: 1\right)$.

5,7-Dihydroxy-4H-chromen-4-one (17): Newly distilled $\mathrm{BF}_{3} \cdot \mathrm{OEt}_{2}(50 \mathrm{~mL}, 0.54 \mathrm{~mol})$ was added slowly to a solution of $16(20.2 \mathrm{~g}, 0.12 \mathrm{mmol})$ in dried DMF $(180 \mathrm{~mL})$ in 1 $\mathrm{h}$ at $\mathrm{rt}$. Then the reaction was transferred to an oil-bath of $50^{\circ} \mathrm{C}$ before the addition of a solution of $\mathrm{MsCl}(32 \mathrm{~mL}, 0.4 \mathrm{~mol})$ in dried $\mathrm{DMF}(72 \mathrm{~mL}, 0.9 \mathrm{~mol})$. The mixture was stirred at $50{ }^{\circ} \mathrm{C}$ for $4 \mathrm{~h}$, and then cooled and poured into $2 \mathrm{~L}$ ice-water. The black solid was filtered off and the filtrate was extracted with EtOAc. Evaporation of the solvent and purification of the residue by flash chromatography $\left(\mathrm{CH}_{2} \mathrm{Cl}_{2}: \mathrm{MeOH}=10\right.$ : 1) yielded yellow solid 17 (8.0 g, 37\% for two steps). $\mathrm{R}_{f} 0.90\left(\mathrm{CHCl}_{3}: \mathrm{MeOH}=10: 1\right)$; ${ }^{1} \mathrm{H}$ NMR (300 MHz, DMSO-d $\left.{ }_{6}\right): \delta=12.07$ (br s, $\left.1 \mathrm{H}\right), 10.92($ br s, $1 \mathrm{H}), 8.18(\mathrm{~d}, J=$ $6.0 \mathrm{~Hz}, 1 \mathrm{H}), 6.38(\mathrm{~d}, J=2.1 \mathrm{~Hz}, 1 \mathrm{H}), 6.28(\mathrm{~d}, J=6.0 \mathrm{~Hz}, 1 \mathrm{H}), 6.21(\mathrm{~d}, J=2.1 \mathrm{~Hz}, 1$ $\mathrm{H})$.

7-Hydroxy-4-oxo-4H-chromen-5-yl hexanoate (18): A similar procedure to the synthesis of 12 was employed. Yield $=64 \% ; \mathrm{R}_{f} 0.21$ (petroleum ether : EtOAc=3 : 1); ${ }^{1} \mathrm{H}$ NMR $\left(300 \mathrm{MHz}, \mathrm{CDCl}_{3}\right): \delta=10.97($ br s, $1 \mathrm{H}), 7.67(\mathrm{~d}, J=9.0 \mathrm{~Hz}, 1 \mathrm{H}), 7.78(\mathrm{~d}$, $J=2.4 \mathrm{~Hz}, 1 \mathrm{H}), 6.59(\mathrm{~d}, J=2.4 \mathrm{~Hz}, 1 \mathrm{H}), 6.09(\mathrm{~d}, J=9.0 \mathrm{~Hz}, 1 \mathrm{H}), 2.71(\mathrm{t}, J=7.5$ Hz, 2 H), 1.80 (m, 2 H), 1.50-1.33 (m, 4 H), 0.94 (t, J=6.9 Hz, 3 H).

5-(Hexanoyloxy)-4-oxo-4H-chromen-7-yl 2,3,5-tri-O-acetyl-a-D-arabinofuranoside (19): A similar procedure to the synthesis of $\mathbf{1 3}$ was employed. Yield = $89 \% . \mathrm{R}_{f} 0.38$ (petroleum ether : EtOAc $\left.=2: 1\right) ;{ }^{1} \mathrm{H}$ NMR $\left(300 \mathrm{MHz}, \mathrm{CDCl}_{3}\right): \delta=7.70$ $(\mathrm{d}, J=6.0 \mathrm{~Hz}, 1 \mathrm{H}), 7.00(\mathrm{~d}, J=2.1 \mathrm{~Hz}, 1 \mathrm{H}), 6.72(\mathrm{~d}, J=2.1 \mathrm{~Hz}, 1 \mathrm{H}), 6.16(\mathrm{~d}, J=$ 
$6.0 \mathrm{~Hz}, 1 \mathrm{H}), 5.77(\mathrm{~s}, 1 \mathrm{H}), 5.37(\mathrm{~s}, 1 \mathrm{H}), 5.11(\mathrm{~d}, J=4.5 \mathrm{~Hz}, 1 \mathrm{H}), 4.47-4.35$ (m, $2 \mathrm{H})$, $4.29(\mathrm{dd}, J=11.4 \mathrm{~Hz}, 4.8 \mathrm{~Hz}, 1 \mathrm{H}), 2.71(\mathrm{t}, J=7.8 \mathrm{~Hz}, 2 \mathrm{H}), 2.16(\mathrm{~s}, 3 \mathrm{H}), 2.15(\mathrm{~s}, 3$ $\mathrm{H}), 2.12(\mathrm{~s}, 3 \mathrm{H}), 1.80-1.70(\mathrm{~m}, 2 \mathrm{H}), 1.45-1.30(\mathrm{~m}, 4 \mathrm{H}), 0.93(\mathrm{t}, J=6.6 \mathrm{~Hz}, 3 \mathrm{H}) ;{ }^{13} \mathrm{C}$ NMR $\left(75 \mathrm{MHz}, \mathrm{CDCl}_{3}\right): \delta=175.7,172.3,170.5,170.1,169.5,159.5,158.7,153.9$, $150.8,113.9,113.5,109.9,103.8,102.1,82.2,81.1,76.7,62.8,34.2,31.3,24.1,22.4$ 20.73, 20.68, 20.65, 13.9; ESI-MS (m/z): $557.3\left(\mathrm{M}+\mathrm{Na}^{+}\right)$; HRMS (MALDI) calcd for $\mathrm{C}_{26} \mathrm{H}_{30} \mathrm{O}_{12} \mathrm{Na}^{+}$557.1630, Found 557.1638.

\section{3-Bromo-5-(hexanoyloxy)-4-0xo-4H-chromen-7-yl}

2,3,5-tri-O-acetyl- $\boldsymbol{\alpha}$-D-arabinofuranoside (20): A similar procedure to the synthesis of 14 was employed. Yield $=63 \% . \mathrm{R}_{f} 0.55$ (petroleum ether $:$ EtOAc $=2: 1$ ). ${ }^{1} \mathrm{H}$ $\operatorname{NMR}\left(300 \mathrm{MHz}, \mathrm{CDCl}_{3}\right): \delta=8.10(\mathrm{~s}, 1 \mathrm{H}), 7.02(\mathrm{~d}, J=1.2 \mathrm{~Hz}, 1 \mathrm{H}), 6.77(\mathrm{~d}, J=1.2$ Hz, $1 \mathrm{H}), 5.77$ (s, $1 \mathrm{H}), 5.38(\mathrm{~s}, 1 \mathrm{H}), 5.12(\mathrm{~d}, J=4.5 \mathrm{~Hz}, 1 \mathrm{H}), 4.48-4.35(\mathrm{~m}, 2 \mathrm{H})$, $4.27(\mathrm{dd}, J=11.4 \mathrm{~Hz}, 4.8 \mathrm{~Hz}, 1 \mathrm{H}), 2.75(\mathrm{t}, J=7.5 \mathrm{~Hz}, 2 \mathrm{H}), 2.16$ (s, $3 \mathrm{H}), 2.15$ (s, 3 H), $2.12(\mathrm{~s}, 3 \mathrm{H}), 1.77$ (q, $J=6.9 \mathrm{~Hz}, 2 \mathrm{H}), 1.45-1.30(\mathrm{~m}, 4 \mathrm{H}), 0.93$ (t, $J=6.6 \mathrm{~Hz}, 3$ $\mathrm{H}) ;{ }^{13} \mathrm{C}$ NMR $\left(75 \mathrm{MHz}, \mathrm{CDCl}_{3}\right): \delta=172.3,170.5,170.1,169.9,169.5,159.8,158.3$, $152.5,150.9,111.6,110.6,103.9,102.0,82.3,81.1,76.6,62.8,57.9,34.1,31.3,24.1$, 22.4, 20.75, 20.70, 20.66, 13.9; ESI-MS (m/z): $635.2\left(\mathrm{M}+\mathrm{Na}^{+}\right)$; HRMS (MALDI) calcd for $\mathrm{C}_{26} \mathrm{H}_{29} \mathrm{O}_{12} \mathrm{BrNa}^{+}$635.0735, Found: 635.0720.

3-Bromo-5-hydroxy-4-oxo-4H-chromen-7-yl $\quad \alpha$-D-arabinofuranoside (21): A similar procedure to the synthesis of $\mathbf{1 5}$ was employed. Yield $=42 \% . \mathrm{R}_{f} 0.47\left(\mathrm{CH}_{2} \mathrm{Cl}_{2}\right.$ : $\mathrm{MeOH}=10: 1) ;[\alpha]_{\mathrm{D}}{ }^{24}=117.6(c 0.28, \mathrm{MeOH}) ;{ }^{1} \mathrm{H}$ NMR $\left(300 \mathrm{MHz}, \mathrm{CD}_{3} \mathrm{OD}\right): \delta=$ $8.47(\mathrm{~s}, 1 \mathrm{H}), 6.70(\mathrm{~d}, J=1.8 \mathrm{~Hz}, 1 \mathrm{H}), 6.54(\mathrm{~d}, J=1.8 \mathrm{~Hz}, 1 \mathrm{H}), 5.65$ (d, J = $1.5 \mathrm{~Hz}$, $1 \mathrm{H}), 4.30(\mathrm{dd}, J=3.9,1.5 \mathrm{~Hz}, 1 \mathrm{H}), 4.08(\mathrm{~m}, 1 \mathrm{H}), 4.03(\mathrm{dd}, J=6.0 \mathrm{~Hz}, 3.9 \mathrm{~Hz}, 1 \mathrm{H})$, $3.80(\mathrm{dd}, J=12.0,2.7 \mathrm{~Hz}, 1 \mathrm{H}), 3.70(\mathrm{dd}, J=12.0,4.8 \mathrm{~Hz}, 1 \mathrm{H}) ;{ }^{13} \mathrm{C} \mathrm{NMR}(75 \mathrm{MHz}$, $\left.\mathrm{CD}_{3} \mathrm{OD}\right): \delta=178.2,165.0,163.0,159.3,157.3,108.9,108.2,107.2,102.0,96.5,87.4$, 
83.9, 78.5, 63.0; ESI-MS (m/z): $410.8\left(\mathrm{M}+\mathrm{Na}^{+}\right)$.

\section{Suzuki-Miyaura coupling}

General procedure A: $\mathrm{Pd}(\mathrm{OAc})_{2}(1.5 \mathrm{mg}, 0.0067 \mathrm{mmol})$, SPhos $(8.0 \mathrm{mg}, 0.0195$ mmol), and $\mathrm{K}_{2} \mathrm{CO}_{3}(54 \mathrm{mg}, 0.390 \mathrm{mmol})$ were added to a solution of 3-bromochromone 15 or 21 (50 mg, $0.129 \mathrm{mmol})$ and aryl boronic acid (0.195 mmol) in acetone- $\mathrm{H}_{2} \mathrm{O}(1: 1,1.0 \mathrm{~mL})$ under the protection of argon. The mixture was stirred in an oil-bath at $50{ }^{\circ} \mathrm{C}$ until TLC indicated the disappearance of the starting material (15 or 21). The reaction solution was then filtered through a silica pad (300 400 mesh) and the filtrate was concentrated in vacuum to give a residue, which was purified by preparative TLC $\left(\mathrm{CH}_{2} \mathrm{Cl}_{2}: \mathrm{MeOH}=8: 1\right)$ to yield the coupling products. The yields are given in Tables 1 and 2.

General procedure B: $\mathrm{Pd}(\mathrm{OAc})_{2}(1.5 \mathrm{mg}, 0.0067 \mathrm{mmol})$, SPhos $(8.0 \mathrm{mg}, 0.0195$ mmol, 0.15 eq.), and $\mathrm{NaOAc}(32 \mathrm{mg}, 0.390 \mathrm{mmol})$ were added to a solution of 3-bromochromone 21 (50 mg, $0.129 \mathrm{mmol})$ and aryl boronic acid (0.195 mmol) in methanol $(0.5 \mathrm{~mL})$ under the protection of argon. The mixture was refluxed in an oil-bath until TLC indicated the disappearance of 21. Similar workup procedure as given in the General procedure A provided the coupling products. The yields are given in Table 2.

8-Hydroxyisoflavon-7-yl $\boldsymbol{\alpha}$-D-arabinofuranoside (22a): $\mathrm{R}_{f} 0.29\left(\mathrm{CHCl}_{3}: \mathrm{MeOH}=\right.$ $10: 1) ;[\alpha]_{\mathrm{D}}{ }^{24}=31.8(c 0.11, \mathrm{MeOH}) ;{ }^{1} \mathrm{H}$ NMR $\left(300 \mathrm{MHz}, \mathrm{CD}_{3} \mathrm{OD}\right): \delta=8.26(\mathrm{~s}, 1 \mathrm{H})$, $7.62(\mathrm{~d}, J=9.0 \mathrm{~Hz}, 1 \mathrm{H}), 7.52(\mathrm{~d}, J=6.3 \mathrm{~Hz}, 2 \mathrm{H}), 7.43-7.35(\mathrm{~m}, 3 \mathrm{H}), 7.31(\mathrm{~d}, J=$ $9.0 \mathrm{~Hz}, 1 \mathrm{H}), 5.73$ ( s, $1 \mathrm{H}), 4.37$ (br s, $1 \mathrm{H}), 4.16$ (dd, J = 8.7 Hz, 4.5 Hz, $1 \mathrm{H}), 4.06$ $(\mathrm{m}, 1 \mathrm{H}), 3.73(\mathrm{dd}, J=11.7 \mathrm{~Hz}, 3.6 \mathrm{~Hz}, 1 \mathrm{H}), 3.68(\mathrm{dd}, J=11.7 \mathrm{~Hz}, 5.4 \mathrm{~Hz}, 1 \mathrm{H}) ;{ }^{13} \mathrm{C}$ NMR (75 MHz, $\left.\mathrm{CD}_{3} \mathrm{OD}\right): \delta=178.5,155.9,149.7,148.3,138.0,133.6,130.6,129.7$ 129.4, 126.1, 121.4, 116.8, 115.8, 109.1, 88.7, 83.0, 78.9, 63.3; ESI-MS (m/z): 387.2 
$\left(\mathrm{M}+\mathrm{H}^{+}\right), 409.2\left(\mathrm{M}+\mathrm{Na}^{+}\right), 425.0\left(\mathrm{M}+\mathrm{K}^{+}\right) ; \mathrm{HRMS}(\mathrm{MALDI})$ calcd for $\mathrm{C}_{20} \mathrm{H}_{18} \mathrm{O}_{8} \mathrm{Na}^{+}$ 409.0894, Found: 409.0902.

8-Hydroxy-4'-methoxyisoflavon-7-yl $\quad$ a-D-arabinofuranoside $\quad(22 b): \quad R_{f} \quad 0.29$ $\left(\mathrm{CHCl}_{3}: \mathrm{MeOH}=10: 1\right) ;[\alpha]_{\mathrm{D}}{ }^{24}=142.4($ c $0.10, \mathrm{MeOH}) ;{ }^{1} \mathrm{H}$ NMR $(300 \mathrm{MHz}$, $\left.\mathrm{CD}_{3} \mathrm{OD}\right): \delta=8.29(\mathrm{~s}, 1 \mathrm{H}), 7.66(\mathrm{~d}, J=8.7 \mathrm{~Hz}, 1 \mathrm{H}), 7.50(\mathrm{~d}, J=8.4 \mathrm{~Hz}, 2 \mathrm{H}), 7.35(\mathrm{~d}$, $J=8.7 \mathrm{~Hz}, 1 \mathrm{H}), 7.01(\mathrm{~d}, J=8.4 \mathrm{~Hz}, 2 \mathrm{H}), 5.77(\mathrm{~s}, 1 \mathrm{H}), 4.41(\mathrm{br} \mathrm{s}, 1 \mathrm{H}), 4.18(\mathrm{dd}, J=$ 8.7 Hz, $4.5 \mathrm{~Hz}, 1 \mathrm{H}), 4.10$ (m, $1 \mathrm{H}), 3.85$ (br s, $3 \mathrm{H}), 3.77$ (dd, $J=11.7 \mathrm{~Hz}, 3.6 \mathrm{~Hz}, 1$ $\mathrm{H}), 3.73(\mathrm{dd}, \mathrm{J}=11.7 \mathrm{~Hz}, 5.1 \mathrm{~Hz}, 1 \mathrm{H}) ;{ }^{13} \mathrm{C} \mathrm{NMR}\left(75 \mathrm{MHz}, \mathrm{CD}_{3} \mathrm{OD}\right): \delta=178.8$, $161.5,155.4,149.6,148.4,138.1,131.7,125.74,125.71,121.4,116.7,115.8,115.2$, 109.1, 88.8, 83.0, 78.9, 63.3, 56.1; ESI-MS (m/z): $417.0\left(\mathrm{M}+\mathrm{H}^{+}\right), 439.0\left(\mathrm{M}+\mathrm{Na}^{+}\right)$, 455.0 $\left(\mathrm{M}+\mathrm{K}^{+}\right)$; HRMS (MALDI) calcd for $\mathrm{C}_{21} \mathrm{H}_{20} \mathrm{O}_{9} \mathrm{Na}^{+} 439.1000$, Found: 439.0999. 8-Hydroxy-2'-methoxyisoflavon-7-yl $\quad \boldsymbol{\alpha}$-D-arabinofuranoside $\quad(22 \mathrm{c}): \mathrm{R}_{f} \quad 0.29$ $\left(\mathrm{CHCl}_{3}: \mathrm{MeOH}=10: 1\right) ;[\alpha]_{\mathrm{D}}{ }^{24}=74.2($ c $0.12, \mathrm{MeOH}) ;{ }^{1} \mathrm{H}$ NMR $(300 \mathrm{MHz}$, $\left.\mathrm{CD}_{3} \mathrm{OD}\right): \delta=8.54($ br s, $1 \mathrm{H}), 8.13(\mathrm{~s}, 1 \mathrm{H}), 7.37(\mathrm{t}, J=7.8 \mathrm{~Hz}, 1 \mathrm{H}), 7.33(\mathrm{~d}, J=8.7$ Hz, $1 \mathrm{H}), 7.28-7.19(\mathrm{~m}, 2 \mathrm{H}), 7.05(\mathrm{~d}, J=8.7 \mathrm{~Hz}, 1 \mathrm{H}), 6.99(\mathrm{t}, J=7.8 \mathrm{~Hz}, 1 \mathrm{H}), 5.68$ (s, $1 \mathrm{H}), 4.39$ (br s, $1 \mathrm{H}), 4.19$ (dd, $J=8.7 \mathrm{~Hz}, 4.5 \mathrm{~Hz}, 1 \mathrm{H}), 4.00(\mathrm{~m}, 1 \mathrm{H}), 3.77$ (br s, $4 \mathrm{H}), 3.70(\mathrm{dd}, J=11.7 \mathrm{~Hz}, 5.4 \mathrm{~Hz}, 1 \mathrm{H})$; ESI-MS $(\mathrm{m} / \mathrm{z}): 439.0\left(\mathrm{M}+\mathrm{Na}^{+}\right)$; HRMS (MALDI) calcd for $\mathrm{C}_{21} \mathrm{H}_{20} \mathrm{O}_{9} \mathrm{Na}^{+} 439.1000$, Found: 439.0990 .

8-Hydroxy-3'-methoxyisoflavon-7-yl $\quad \boldsymbol{\alpha}$-D-arabinofuranoside $\quad$ (22d): $\mathrm{R}_{f} \quad 0.29$ $\left(\mathrm{CHCl}_{3}: \mathrm{MeOH}=10: 1\right) ;[\alpha]_{\mathrm{D}}{ }^{24}=27.6($ c $0.13, \mathrm{MeOH}) ;{ }^{1} \mathrm{H}$ NMR $(300 \mathrm{MHz}$, $\left.\mathrm{CD}_{3} \mathrm{OD}\right): \delta=8.33(\mathrm{~s}, 1 \mathrm{H}), 7.54(\mathrm{~d}, J=9.0 \mathrm{~Hz}, 1 \mathrm{H}), 7.36(\mathrm{t}, J=7.2 \mathrm{~Hz}, 1 \mathrm{H}), 7.31(\mathrm{~d}$, $J=9 \mathrm{~Hz}, 1 \mathrm{H}), 7.16($ br s, $1 \mathrm{H}), 7.12(\mathrm{~d}, J=7.5 \mathrm{~Hz}, 1 \mathrm{H}), 6.97($ br d, $J=7.2 \mathrm{~Hz}, 1 \mathrm{H})$, $5.73(\mathrm{~s}, 1 \mathrm{H}), 4.40($ br s, $1 \mathrm{H}), 4.19(\mathrm{dd}, J=8.7 \mathrm{~Hz}, 4.5 \mathrm{~Hz}, 1 \mathrm{H}), 4.05(\mathrm{~m}, 1 \mathrm{H}), 3.85$ (s, $3 \mathrm{H}), 3.83-3.65(\mathrm{~m}, 2 \mathrm{H}) ;{ }^{13} \mathrm{C}$ NMR $\left(75 \mathrm{MHz}, \mathrm{CD}_{3} \mathrm{OD}\right): \delta=179.1,161.4,156.1$, $150.5,145.9,144.5,135.2,130.7,125.6,122.8,121.7,116.4,116.2,115.0,113.8$ 
109.1, 88.5, 83.0, 78.9, 63.3, 56.1; ESI-MS (m/z): $417.2\left(\mathrm{M}+\mathrm{H}^{+}\right), 439.2\left(\mathrm{M}+\mathrm{Na}^{+}\right)$, 455.2 $\left(\mathrm{M}+\mathrm{K}^{+}\right.$); HRMS (MALDI) calcd for $\mathrm{C}_{21} \mathrm{H}_{21} \mathrm{O}_{9}{ }^{+}$417.1180, Found: 417.1188.

8-Hydroxy-4'-methylisoflavon-7-yl $\alpha$-D-arabinofuranoside (22e): $\mathrm{R}_{f} \quad 0.27\left(\mathrm{CHCl}_{3}\right.$ : $\mathrm{MeOH}=10: 1) ;[\alpha]_{\mathrm{D}}{ }^{24}=37.1(c 0.17, \mathrm{MeOH}) ;{ }^{1} \mathrm{H}$ NMR $\left(300 \mathrm{MHz}, \mathrm{CD}_{3} \mathrm{OD}\right): \delta=$ $8.18(\mathrm{~s}, 1 \mathrm{H}), 7.54(\mathrm{~d}, J=9.0 \mathrm{~Hz}, 1 \mathrm{H}), 7.34(\mathrm{~d}, J=7.5 \mathrm{~Hz}, 2 \mathrm{H}), 7.24(\mathrm{~d}, J=9.0 \mathrm{~Hz}$, $1 \mathrm{H}), 7.15(\mathrm{~d}, J=7.5 \mathrm{~Hz}, 2 \mathrm{H}), 5.66(\mathrm{~s}, 1 \mathrm{H}), 4.30(\mathrm{br} \mathrm{s}, 1 \mathrm{H}), 4.08(\mathrm{dd}, J=8.7 \mathrm{~Hz}, 4.5$ Hz, $1 \mathrm{H}), 3.98($ br s, $1 \mathrm{H}), 3.66(\mathrm{dd}, J=11.7 \mathrm{~Hz}, 3.9 \mathrm{~Hz}, 1 \mathrm{H}), 3.62(\mathrm{dd}, J=11.7 \mathrm{~Hz}$, $4.8 \mathrm{~Hz}, 1 \mathrm{H}), 2.28(\mathrm{~s}, 3 \mathrm{H})$; ESI-MS (m/z): $401.0\left(\mathrm{M}+\mathrm{H}^{+}\right), 423.0\left(\mathrm{M}+\mathrm{Na}^{+}\right)$; HRMS (MALDI) calcd for $\mathrm{C}_{21} \mathrm{H}_{21} \mathrm{O}_{8}{ }^{+}$401.1231, Found: 401.1235 .

8-Hydroxy-2'-methylisoflavon-7-yl $\boldsymbol{\alpha}$-D-arabinofuranoside (22f): $\mathrm{R}_{f} 0.39\left(\mathrm{CHCl}_{3}\right.$ : $\mathrm{MeOH}=10: 1) ;[\alpha]_{\mathrm{D}}{ }^{24}=52.1(c 0.10, \mathrm{MeOH}) ;{ }^{1} \mathrm{H}$ NMR $\left(300 \mathrm{MHz}, \mathrm{CD}_{3} \mathrm{OD}\right): \delta=$ $8.13(\mathrm{~s}, 1 \mathrm{H}), 7.40(\mathrm{~d}, J=8.7 \mathrm{~Hz}, 1 \mathrm{H}), 7.34-7.16(\mathrm{~m}, 5 \mathrm{H}), 5.71(\mathrm{~s}, 1 \mathrm{H}), 4.39$ (br s, 1 H), $4.20(\mathrm{dd}, J=8.7 \mathrm{~Hz}, 4.5 \mathrm{~Hz}, 1 \mathrm{H}), 4.03(\mathrm{~m}, 1 \mathrm{H}), 3.76(\mathrm{dd}, J=11.7 \mathrm{~Hz}, 3.9 \mathrm{~Hz}, 1$ H), $3.67(\mathrm{dd}, J=11.7 \mathrm{~Hz}, 5.1 \mathrm{~Hz}, 1 \mathrm{H}), 2.21(\mathrm{~s}, 3 \mathrm{H})$; ESI-MS (m/z): $401.2\left(\mathrm{M}+\mathrm{H}^{+}\right)$, $423.2\left(\mathrm{M}+\mathrm{Na}^{+}\right), 439.0\left(\mathrm{M}+\mathrm{K}^{+}\right)$; HRMS (MALDI) calcd for $\mathrm{C}_{21} \mathrm{H}_{20} \mathrm{O}_{8} \mathrm{Na}^{+}$423.1050, Found: 423.1058 .

8-Hydroxy-3'-methylisoflavon-7-yl $\alpha$-D-arabinofuranoside (22g): $\mathrm{R}_{f} \quad 0.35\left(\mathrm{CHCl}_{3}\right.$ : $\mathrm{MeOH}=10: 1) ;[\alpha]_{\mathrm{D}}{ }^{24}=17.7(c 0.13, \mathrm{MeOH}) ;{ }^{1} \mathrm{H}$ NMR $\left(300 \mathrm{MHz}, \mathrm{CD}_{3} \mathrm{O} \mathrm{D}\right): \delta=$ $8.32(\mathrm{~s}, 1 \mathrm{H})$, 7.78-7.63 (m, $2 \mathrm{H}), 7.42-7.29$ (m, $3 \mathrm{H}), 7.22$ (br s, $1 \mathrm{H}), 5.79(\mathrm{~s}, 1 \mathrm{H})$, $4.43($ br s, $1 \mathrm{H}), 4.21(\mathrm{dd}, J=8.7 \mathrm{~Hz}, 4.5 \mathrm{~Hz}, 1 \mathrm{H}), 4.10(\mathrm{~m}, 1 \mathrm{H}), 3.78(\mathrm{dd}, J=11.7$ Hz, 3.9 Hz, $1 \mathrm{H}), 3.71(\mathrm{dd}, J=11.7 \mathrm{~Hz}, 5.1 \mathrm{~Hz}, 1 \mathrm{H}), 2.41(\mathrm{~s}, 3 \mathrm{H})$; ESI-MS (m/z): $401.2\left(\mathrm{M}+\mathrm{H}^{+}\right), 423.2\left(\mathrm{M}+\mathrm{Na}^{+}\right), 439.2\left(\mathrm{M}+\mathrm{K}^{+}\right)$; HRMS (ESI) calcd for $\mathrm{C}_{21} \mathrm{H}_{20} \mathrm{O}_{8} \mathrm{Na}^{+}$423.1050, Found: 423.1051.

4',8-Dihydroxyisoflavon-7-yl $\alpha$-D-arabinofuranoside $(22 \mathrm{~h}, \mathrm{~A}-76202)^{[10]}$

3',8-Dihydroxyisoflavon-7-yl $\alpha$-D-arabinofuranoside (22i): $\mathrm{R}_{f} \quad 0.23 \quad\left(\mathrm{CHCl}_{3}\right.$ : 
$\mathrm{MeOH}=8: 1) ;[\alpha]_{\mathrm{D}}{ }^{24}=99.7(c 0.08, \mathrm{MeOH}) ;{ }^{1} \mathrm{H}$ NMR $\left(300 \mathrm{MHz}, \mathrm{CD}_{3} \mathrm{OD}\right): \delta=8.31$ (s, $1 \mathrm{H}), 7.67(\mathrm{~d}, J=8.7 \mathrm{~Hz}, 1 \mathrm{H}), 7.37$ (d, $J=8.7 \mathrm{~Hz}, 1 \mathrm{H}), 7.28(\mathrm{t}, J=7.5 \mathrm{~Hz}, 1 \mathrm{H})$, 7.05 (br s, $1 \mathrm{H}), 7.03(\mathrm{~d}, J=8.1 \mathrm{~Hz}, 1 \mathrm{H}), 6.85($ br d, $J=6.6 \mathrm{~Hz}, 1 \mathrm{H}), 5.79(\mathrm{~s}, 1 \mathrm{H})$, 4.43 (br s, $1 \mathrm{H}), 4.22$ (dd, $J=8.7 \mathrm{~Hz}, 4.5 \mathrm{~Hz}, 1 \mathrm{H}), 4.11(\mathrm{~m}, 1 \mathrm{H}), 3.79$ (dd, $J=11.7$ $\mathrm{Hz}, 3.9 \mathrm{~Hz}, 1 \mathrm{H}), 3.74(\mathrm{dd}, J=11.7 \mathrm{~Hz}, 5.1 \mathrm{~Hz}, 1 \mathrm{H}) ;{ }^{13} \mathrm{C} \mathrm{NMR}\left(75 \mathrm{MHz}, \mathrm{CD}_{3} \mathrm{OD}\right): \delta$ $=178.6,158.8,155.7,150.0,148.7,138.9,134.9,130.7,126.2,121.7,117.7,116.5$, 116.4, 116.2, 109.4, 88.9, 83.0, 79.0, 63.4; ESI-MS (m/z): $403.0\left(\mathrm{M}+\mathrm{H}^{+}\right), 425.0(\mathrm{M}$ $+\mathrm{Na}^{+}$); HRMS (MALDI) calcd for $\mathrm{C}_{20} \mathrm{H}_{19} \mathrm{O}_{9}{ }^{+}$403.1024, Found: 403.1028 .

4'-Fluoro-8-hydroxyisoflavon-7-yl $\boldsymbol{\alpha}$-D-arabinofuranoside (22j): $\mathrm{R}_{f} 0.42\left(\mathrm{CHCl}_{3}\right.$ : $\mathrm{MeOH}=8: 1) ;[\alpha]_{\mathrm{D}}{ }^{24}=31.6(c 0.16, \mathrm{MeOH}) ;{ }^{1} \mathrm{H}$ NMR $\left(300 \mathrm{MHz}, \mathrm{CD}_{3} \mathrm{OD}\right): \delta=8.34$ (s, $1 \mathrm{H}), 7.65-7.56(\mathrm{~m}, 3 \mathrm{H}), 7.34(\mathrm{~d}, J=9.0 \mathrm{~Hz}, 1 \mathrm{H}), 7.19$ (t, $J=8.4 \mathrm{~Hz}, 2 \mathrm{H}), 5.77$ (s, $1 \mathrm{H}), 4.41$ (br s, $1 \mathrm{H}), 4.21$ (dd, $J=8.7 \mathrm{~Hz}, 4.5 \mathrm{~Hz}, 1 \mathrm{H}), 4.09$ (m, $1 \mathrm{H}), 3.78$ (dd, $J$ $=11.7 \mathrm{~Hz}, 3.9 \mathrm{~Hz}, 1 \mathrm{H}), 3.73(\mathrm{dd}, J=11.7 \mathrm{~Hz}, 5.1 \mathrm{~Hz}, 1 \mathrm{H})$; ESI-MS (m/z): $405.2(\mathrm{M}$ $\left.+\mathrm{H}^{+}\right), 427.2\left(\mathrm{M}+\mathrm{Na}^{+}\right)$; HRMS (ESI) calcd for $\mathrm{C}_{20} \mathrm{H}_{17} \mathrm{O}_{8} \mathrm{FNa}^{+}$427.0800, Found: 427.0795 .

4'-(Dimethylamino)-8-hydroxyisoflavon-7-yl a-D-arabinofuranoside (22k): $\mathrm{R}_{f}$ $0.30\left(\mathrm{CHCl}_{3}: \mathrm{MeOH}=10: 1\right) ;[\alpha]_{\mathrm{D}}{ }^{24}=104.6(c$ 0.10, MeOH$) ;{ }^{1} \mathrm{H}$ NMR $(300 \mathrm{MHz}$, $\left.\mathrm{CD}_{3} \mathrm{OD}\right): \delta=8.22(\mathrm{~s}, 1 \mathrm{H}), 7.43(\mathrm{~d}, J=8.4 \mathrm{~Hz}, 3 \mathrm{H}), 7.25(\mathrm{~d}, J=9.0 \mathrm{~Hz}, 1 \mathrm{H}), 6.84(\mathrm{~d}$, $J=8.4 \mathrm{~Hz}, 2 \mathrm{H}), 5.69(\mathrm{~s}, 1 \mathrm{H}), 4.40($ br s, $1 \mathrm{H}), 4.20(\mathrm{dd}, J=8.7 \mathrm{~Hz}, 4.5 \mathrm{~Hz}, 1 \mathrm{H})$, $4.02(\mathrm{~m}, 1 \mathrm{H}), 3.77$ (dd, $J=11.7 \mathrm{~Hz}, 3.0 \mathrm{~Hz}, 1 \mathrm{H}), 3.71(\mathrm{dd}, J=11.7 \mathrm{~Hz}, 5.1 \mathrm{~Hz}, 1 \mathrm{H})$, 2.96 (br s, $6 \mathrm{H}) ;{ }^{13} \mathrm{C}$ NMR (75 MHz, $\left.\mathrm{CD}_{3} \mathrm{OD}\right): \delta=180.0,155.0,152.3,150.6,144.4$, 131.1, 125.6, 122.1, 116.7, 124.0, 112.1, 109.1, 88.3, 83.0, 79.0, 63.4, 41.1; ESI-MS $(\mathrm{m} / \mathrm{z}): 430.0\left(\mathrm{M}+\mathrm{H}^{+}\right)$; HRMS (ESI) calcd for $\mathrm{C}_{22} \mathrm{H}_{23} \mathrm{O}_{8} \mathrm{NNa}^{+}$452.1316, Found: 452.1320.

4'-(tert-Butoxycarbonylamino)-8-hydroxyisoflavon-7-yl a-D-arabinofuranoside 
(22I): $\mathrm{R}_{f} 0.42\left(\mathrm{CHCl}_{3}: \mathrm{MeOH}=10: 1\right) ;[\alpha]_{\mathrm{D}}{ }^{24}=45.6($ c $0.10, \mathrm{MeOH}) ;{ }^{1} \mathrm{H} \mathrm{NMR}$ (300 MHz, $\left.\mathrm{CD}_{3} \mathrm{OD}\right): \delta=8.57(\mathrm{~s}, 1 \mathrm{H}), 8.28(\mathrm{~s}, 1 \mathrm{H}), 7.60(\mathrm{~d}, J=9.0 \mathrm{~Hz}, 1 \mathrm{H}), 7.48$ (br s, $4 \mathrm{H}), 7.31$ (d, $J=9.0 \mathrm{~Hz}, 1 \mathrm{H}), 5.75$ (s, $1 \mathrm{H}), 4.40$ (br s, $1 \mathrm{H}), 4.17$ (dd, $J=8.7$ Hz, 4.5 Hz, 1 H), 4.07 (m, $1 \mathrm{H}), 3.79$ (dd, $J=11.7 \mathrm{~Hz}, 3.9 \mathrm{~Hz}, 1 \mathrm{H}), 3.71(\mathrm{dd}, J=11.7$ Hz, $5.1 \mathrm{~Hz}, 1 \mathrm{H}), 1.53(\mathrm{~s}, 9 \mathrm{H})$; ESI-MS (m/z): $502.0\left(\mathrm{M}+\mathrm{H}^{+}\right), 524.0\left(\mathrm{M}+\mathrm{Na}^{+}\right)$; HRMS (MALDI) calcd for $\mathrm{C}_{25} \mathrm{H}_{27} \mathrm{O}_{10} \mathrm{NNa}^{+}$524.1527, Found: 524.1532.

8-Hydroxy-4'-(trifluoromethyl)isoflavon-7-yl $\alpha$-D-arabinofuranoside (22m): $\mathrm{R}_{f}$ $0.43\left(\mathrm{CHCl}_{3}: \mathrm{MeOH}=10: 1\right) ;[\alpha]_{\mathrm{D}}{ }^{24}=37.5($ c $0.23, \mathrm{MeOH}) ;{ }^{1} \mathrm{H}$ NMR $(300 \mathrm{MHz}$, $\left.\mathrm{CDCl}_{3}\right): \delta=8.41(\mathrm{~s}, 1 \mathrm{H}), 7.83-7.65(\mathrm{~m}, 4 \mathrm{H}), 7.57(\mathrm{~d}, J=8.4 \mathrm{~Hz}, 1 \mathrm{H}), 7.32(\mathrm{~d}, J=$ $7.8 \mathrm{~Hz}, 1 \mathrm{H}), 5.77$ (s, $1 \mathrm{H}), 4.42$ (br s, $1 \mathrm{H}), 4.21$ (dd, J = 7.8 Hz, $4.5 \mathrm{~Hz}, 1 \mathrm{H}), 4.09$ (m, $1 \mathrm{H}), 3.82-3.74(\mathrm{~m}, 2 \mathrm{H}) ;{ }^{13} \mathrm{C}$ NMR $\left(75 \mathrm{MHz}, \mathrm{CD}_{3} \mathrm{OD}\right): \delta=178.3,156.4,150.3$, $149.1,140.6,138.1,131.1,126.4,124.6,121.7,116.4,115.1,109.3,88.9,82.8,79.0$, 63.4, 31.0; ESI-MS (m/z): $455.0\left(\mathrm{M}+\mathrm{H}^{+}\right), 477.0\left(\mathrm{M}+\mathrm{Na}^{+}\right)$; HRMS (ESI) calcd for $\mathrm{C}_{21} \mathrm{H}_{17} \mathrm{O}_{8} \mathrm{~F}_{3} \mathrm{Na}^{+}$477.0768, Found: 477.0768.

8-Hydroxy-4'-(trimethylsilyl)isoflavon-7-yl $\alpha$-D-arabinofuranoside (22n): $R_{f} \quad 0.58$ $\left(\mathrm{CH}_{2} \mathrm{Cl}_{2}: \mathrm{MeOH}=8: 1\right) ;[\alpha]_{\mathrm{D}}{ }^{24}=49.1($ c $0.12, \mathrm{MeOH}) ;{ }^{1} \mathrm{H}$ NMR $(300 \mathrm{MHz}$, $\left.\mathrm{CD}_{3} \mathrm{OD}\right): \delta=8.32(\mathrm{~s}, 1 \mathrm{H}), 7.71-7.46(\mathrm{~m}, 5 \mathrm{H}), 7.32(\mathrm{~d}, J=8.7 \mathrm{~Hz}, 1 \mathrm{H}), 5.76(\mathrm{~s}, 1 \mathrm{H})$, 4.42 (br s, $1 \mathrm{H}), 4.21$ (dd, $J=8.7 \mathrm{~Hz}, 4.5 \mathrm{~Hz}, 1 \mathrm{H}$ ), 4.07 (br s, $1 \mathrm{H}), 3.86-3.64$ (m, 2 H), 0.30 (s, 9 H); ESI-MS (m/z): $459.0\left(\mathrm{M}+\mathrm{H}^{+}\right)$.

5-Hydroxyisoflavon-7-yl $\boldsymbol{\alpha}$-D-arabinofuranoside (23a): $\mathrm{R}_{f} 0.42\left(\mathrm{CH}_{2} \mathrm{Cl}_{2}: \mathrm{MeOH}=\right.$ $10: 1) ;[\alpha]_{\mathrm{D}}{ }^{24}=86.7(c 0.15, \mathrm{MeOH}) ;{ }^{1} \mathrm{H}$ NMR $\left(300 \mathrm{MHz}, \mathrm{CD}_{3} \mathrm{OD}\right): \delta=8.20(\mathrm{~s}, 1 \mathrm{H})$, $7.56(\mathrm{~d}, J=6.6 \mathrm{~Hz}, 2 \mathrm{H}), 7.48-7.34(\mathrm{~m}, 3 \mathrm{H}), 6.70$ (br s, $1 \mathrm{H}), 6.50$ (br s, $1 \mathrm{H}), 5.65$ (s, $1 \mathrm{H}), 4.29$ (br s, $1 \mathrm{H}), 4.13-3.96(\mathrm{~m}, 2 \mathrm{H}), 3.78(\mathrm{dd}, J=12.0 \mathrm{~Hz}, 2.4 \mathrm{~Hz}, 1 \mathrm{H}), 3.69$ $(\mathrm{dd}, J=12.0 \mathrm{~Hz}, 4.5 \mathrm{~Hz}, 1 \mathrm{H})$; ESI-MS (m/z): $387.0\left(\mathrm{M}+\mathrm{H}^{+}\right), 409.0\left(\mathrm{M}+\mathrm{Na}^{+}\right)$; HRMS (ESI) calcd for $\mathrm{C}_{20} \mathrm{H}_{19} \mathrm{O}_{8}{ }^{+} 387.1074$, Found: 387.1075 . 
5-Hydroxy-4'-methoxyisoflavon-7-yl $\quad \boldsymbol{\alpha}$-D-arabinofuranoside $\quad$ (23b): $\quad \mathrm{R}_{f} \quad 0.48$ $\left(\mathrm{CH}_{2} \mathrm{Cl}_{2}: \mathrm{MeOH}=10: 1\right) ;[\alpha]_{\mathrm{D}}{ }^{24}=68.6(c$ 0.19, MeOH$) ;{ }^{1} \mathrm{H}$ NMR $(300 \mathrm{MHz}$, $\left.\mathrm{CD}_{3} \mathrm{OD}\right): \delta=8.17(\mathrm{~s}, 1 \mathrm{H}), 7.50(\mathrm{~d}, J=7.2 \mathrm{~Hz}, 2 \mathrm{H}), 6.99(\mathrm{~d}, J=7.2 \mathrm{~Hz}, 2 \mathrm{H}), 6.69$ (br s, $1 \mathrm{H}), 6.50$ (br s, $1 \mathrm{H}), 5.67(\mathrm{~s}, 1 \mathrm{H}), 4.31$ (br s, $1 \mathrm{H}), 4.13-4.02(\mathrm{~m}, 2 \mathrm{H}), 3.84$ (s, $3 \mathrm{H}), 3.80(\mathrm{dd}, J=12.0 \mathrm{~Hz}, 3.0 \mathrm{~Hz}, 1 \mathrm{H}), 3.73$ (dd, $J=12.0,4.5 \mathrm{~Hz}, 1 \mathrm{H})$; ESI-MS $(\mathrm{m} / \mathrm{z}): 417.0\left(\mathrm{M}+\mathrm{H}^{+}\right), 439.0\left(\mathrm{M}+\mathrm{Na}^{+}\right)$; HRMS (MALDI) calcd for $\mathrm{C}_{21} \mathrm{H}_{21} \mathrm{O}_{9}{ }^{+}$ 417.1180, Found: 417.1186.

5-Hydroxy-2'-methoxyisoflavon-7-yl $\quad \boldsymbol{\alpha}$-D-arabinofuranoside $\quad(23 c): \quad R_{f} \quad 0.49$ $\left(\mathrm{CH}_{2} \mathrm{Cl}_{2}: \mathrm{MeOH}=10: 1\right) ;[\alpha]_{\mathrm{D}}{ }^{24}=74.6(c 0.19, \mathrm{MeOH}) ;{ }^{1} \mathrm{H}$ NMR $(300 \mathrm{MHz}$, $\left.\mathrm{CD}_{3} \mathrm{OD}\right): \delta=8.28(\mathrm{~s}, 1 \mathrm{H}), 7.63(\mathrm{t}, J=8.4 \mathrm{~Hz}, 1 \mathrm{H}), 7.50(\mathrm{~d}, J=7.2 \mathrm{~Hz}, 1 \mathrm{H}), 7.30(\mathrm{~d}$, $J=8.4 \mathrm{~Hz}, 1 \mathrm{H}), 7.24(\mathrm{t}, J=7.2 \mathrm{~Hz}, 1 \mathrm{H}), 6.93(\mathrm{~d}, J=1.8 \mathrm{~Hz}, 1 \mathrm{H}), 6.74(\mathrm{~d}, J=1.8$ $\mathrm{Hz}, 1 \mathrm{H}), 5.89(\mathrm{~s}, 1 \mathrm{H}), 4.53(\mathrm{~d}, J=2.1 \mathrm{~Hz}, 1 \mathrm{H}), 4.35-4.22(\mathrm{~m}, 2 \mathrm{H}), 4.04(\mathrm{dd}, J=$ 12.0 Hz, 3.0 Hz, 1 H), 4.03 (s, $3 \mathrm{H}), 3.93$ (dd, J = 12.0 Hz, 4.5 Hz, 1 H); ESI-MS $(\mathrm{m} / \mathrm{z})$ : $417.2\left(\mathrm{M}+\mathrm{H}^{+}\right)$; HRMS (ESI) calcd for $\mathrm{C}_{21} \mathrm{H}_{21} \mathrm{O}_{9}{ }^{+}$417.1180, Found: 417.1190.

5-Hydroxy-3'-methoxyisoflavon-7-yl $\quad \boldsymbol{\alpha}$-D-arabinofuranoside $\quad$ (23d): $\quad R_{f} \quad 0.47$ $\left(\mathrm{CH}_{2} \mathrm{Cl}_{2}: \mathrm{MeOH}=10: 1\right) ;[\alpha]_{\mathrm{D}}{ }^{24}=89.2(c 0.08, \mathrm{MeOH}) ;{ }^{1} \mathrm{H}$ NMR $(300 \mathrm{MHz}$, $\left.\mathrm{CD}_{3} \mathrm{OD}\right): \delta=8.22($ br s, $1 \mathrm{H}), 7.34(\mathrm{t}, J=7.5 \mathrm{~Hz}, 1 \mathrm{H}), 7.15($ br s, $1 \mathrm{H}), 7.11(\mathrm{~d}, J=$ $7.5 \mathrm{~Hz}, 1 \mathrm{H}), 6.96(\mathrm{~d}, J=7.5 \mathrm{~Hz}, 1 \mathrm{H}), 6.70(\mathrm{~d}, J=1.5 \mathrm{~Hz}, 1 \mathrm{H}), 6.51(\mathrm{~d}, J=1.5 \mathrm{~Hz}, 1$ H), 5.65 (br s, $1 \mathrm{H}), 4.29$ (d, J=3.6 Hz, $1 \mathrm{H}), 4.10-3.98(\mathrm{~m}, 2 \mathrm{H}), 3.82(\mathrm{~s}, 3 \mathrm{H}), 3.78$ $(\mathrm{dd}, J=12.0,3.0 \mathrm{~Hz}, 1 \mathrm{H}), 3.70(\mathrm{dd}, J=12.0 \mathrm{~Hz}, 4.5 \mathrm{~Hz})$; ESI-MS (m/z): $417.2(\mathrm{M}+$ $\left.\mathrm{H}^{+}\right), 439.2\left(\mathrm{M}+\mathrm{Na}^{+}\right)$; HRMS (ESI) calcd for $\mathrm{C}_{21} \mathrm{H}_{21} \mathrm{O}_{9}{ }^{+}$417.1180, Found: 417.1178.

5-Hydroxy-4'-methylisoflavon-7-yl $\alpha$-D-arabinofuranoside (23e): $\mathrm{R}_{f} 0.50\left(\mathrm{CH}_{2} \mathrm{Cl}_{2}\right.$ : $\mathrm{MeOH}=10: 1) ;[\alpha]_{\mathrm{D}}{ }^{24}=136.7(c 0.13, \mathrm{MeOH}) ;{ }^{1} \mathrm{H}$ NMR $\left(300 \mathrm{MHz}, \mathrm{CD}_{3} \mathrm{OD}\right): \delta=$ $8.16(\mathrm{~s}, 1 \mathrm{H}), 7.43$ (d, J = 7.8 Hz, $2 \mathrm{H}), 7.24$ (d, J = 7.8 Hz, $2 \mathrm{H}), 6.68$ (br s, $1 \mathrm{H}), 6.49$ (br s, $1 \mathrm{H}), 5.64(\mathrm{~s}, 1 \mathrm{H}), 4.29$ (br s, $1 \mathrm{H}), 4.13-3.98(\mathrm{~m}, 2 \mathrm{H}), 4.06$ (dd, $J=12.0 \mathrm{~Hz}$, 
3.0 Hz, $1 \mathrm{H}), 3.98$ (dd, $J=12.0 \mathrm{~Hz}, 4.5 \mathrm{~Hz}, 1 \mathrm{H}), 2.37$ (s, $3 \mathrm{H})$; ESI-MS (m/z): 401.1 $\left(\mathrm{M}+\mathrm{H}^{+}\right), 423.1\left(\mathrm{M}+\mathrm{Na}^{+}\right)$; HRMS (ESI) calcd for $\mathrm{C}_{21} \mathrm{H}_{21} \mathrm{O}_{8}{ }^{+}$401.1231, Found: 401.1232 .

5-Hydroxy-3'-methylisoflavon-7-yl $\boldsymbol{\alpha}$-D-arabinofuranoside (23f): $\mathrm{R}_{f} 0.49\left(\mathrm{CH}_{2} \mathrm{Cl}_{2}\right.$ : $\mathrm{MeOH}=10: 1) ;[\alpha]_{\mathrm{D}}{ }^{24}=97.6(c 0.10, \mathrm{MeOH}) ;{ }^{1} \mathrm{H}$ NMR $\left(300 \mathrm{MHz}, \mathrm{CD}_{3} \mathrm{OD}\right): \delta=$ $8.16(\mathrm{~s}, 1 \mathrm{H}), 7.40-7.30(\mathrm{~m}, 3 \mathrm{H}), 7.22-7.18(\mathrm{~d}, J=7.2 \mathrm{~Hz}, 1 \mathrm{H}), 6.69$ (br s, $1 \mathrm{H}), 6.51$ (br s, $1 \mathrm{H}), 5.64$ (br s, $1 \mathrm{H}), 4.28$ (br s, $1 \mathrm{H}), 4.12-3.98$ (m, $2 \mathrm{H}), 3.84-3.63$ (m, $2 \mathrm{H})$, $2.39(\mathrm{~s}, 3 \mathrm{H})$; ESI-MS (m/z): $401.1\left(\mathrm{M}+\mathrm{H}^{+}\right), 423.0\left(\mathrm{M}+\mathrm{Na}^{+}\right)$; HRMS (ESI) calcd for $\mathrm{C}_{21} \mathrm{H}_{20} \mathrm{O}_{8} \mathrm{Na}^{+}$423.1050, Found: 423.1050 .

4',5-Dihydroxyisoflavon-7-yl $\boldsymbol{\alpha}$-D-arabinofuranoside (23g): $\mathrm{R}_{f} \quad 0.28 \quad\left(\mathrm{CH}_{2} \mathrm{Cl}_{2}\right.$ : $\mathrm{MeOH}=10: 1) ;[\alpha]_{\mathrm{D}}{ }^{24}=37.1(c 0.15, \mathrm{MeOH}) ;{ }^{1} \mathrm{H}$ NMR $\left(300 \mathrm{MHz}, \mathrm{CD}_{3} \mathrm{OD}\right): \delta=$ $8.15(\mathrm{~s}, 1 \mathrm{H}), 7.39$ (d, $J=8.4 \mathrm{~Hz}, 2 \mathrm{H}), 6.85(\mathrm{~d}, J=8.4 \mathrm{~Hz}, 2 \mathrm{H}), 6.69(\mathrm{~d}, J=1.5 \mathrm{~Hz}$ $1 \mathrm{H}), 6.50(\mathrm{~d}, J=1.5 \mathrm{~Hz}, 1 \mathrm{H}), 5.65(\mathrm{br} \mathrm{s}, 1 \mathrm{H}), 4.29(\mathrm{~d}, J=3.6 \mathrm{~Hz}, 1 \mathrm{H}), 4.07(\mathrm{~m}, 1$ H), $4.02(\mathrm{dd}, J=6.6 \mathrm{~Hz}, 3.9 \mathrm{~Hz}, 1 \mathrm{H}), 3.78(\mathrm{dd}, J=12.0,2.7 \mathrm{~Hz}, 1 \mathrm{H}), 3.70(\mathrm{dd}, J=$ 12.0, $4.5 \mathrm{~Hz}, 1 \mathrm{H})$; ESI-MS $(\mathrm{m} / \mathrm{z}): 403.1\left(\mathrm{M}+\mathrm{H}^{+}\right), 425.2\left(\mathrm{M}+\mathrm{Na}^{+}\right)$; HRMS (ESI) calcd for $\mathrm{C}_{20} \mathrm{H}_{19} \mathrm{O}_{9}{ }^{+} 403.1024$, Found: 403.1025 .

3',5-Dihydroxyisoflavon-7-yl $\boldsymbol{\alpha}$-D-arabinofuranoside (23h): $\mathrm{R}_{f} \quad 0.29 \quad\left(\mathrm{CH}_{2} \mathrm{Cl}_{2}\right.$ : $\mathrm{MeOH}=10: 1) ;[\alpha]_{\mathrm{D}}{ }^{24}=49.2(c 0.17, \mathrm{MeOH}) ;{ }^{1} \mathrm{H}$ NMR $\left(300 \mathrm{MHz}, \mathrm{CD}_{3} \mathrm{OD}\right): \delta=$ $8.18(\mathrm{~s}, 1 \mathrm{H}), 7.24$ (t, J=7.8 Hz, $1 \mathrm{H}), 7.02$ (br s, $1 \mathrm{H}), 7.00(\mathrm{~d}, J=7.8 \mathrm{~Hz}, 1 \mathrm{H}), 6.82$ $(\mathrm{d}, J=7.8 \mathrm{~Hz}, 1 \mathrm{H}), 6.69$ (br s, $1 \mathrm{H}), 6.50($ br s, $1 \mathrm{H}), 5.65(\mathrm{~s}, 1 \mathrm{H}), 4.29(\mathrm{~d}, J=3.0 \mathrm{~Hz}$, $1 \mathrm{H}), 4.07(\mathrm{~m}, 1 \mathrm{H}), 4.03(\mathrm{dd}, J=6.6 \mathrm{~Hz}, 3.9 \mathrm{~Hz}, 1 \mathrm{H}), 3.79(\mathrm{dd}, J=12.0,2.7 \mathrm{~Hz}, 1$ H), $3.69(\mathrm{dd}, J=12.0,4.8 \mathrm{~Hz}, 1 \mathrm{H})$; ESI-MS $(\mathrm{m} / \mathrm{z})$ : $403.1\left(\mathrm{M}+\mathrm{H}^{+}\right)$; HRMS (MALDI) calcd for $\mathrm{C}_{20} \mathrm{H}_{19} \mathrm{O}_{9}^{+}$403.1024, Found: 403.1030 .

\section{Acknowledgements}


This work is supported by the Chinese Academy of Sciences (KGCX2-SW-213 and KGCX2-SW-209) and the National Natural Science Foundation of China (20321202).

\section{References}

[1] B. Imperiali, V. W.-F. Tai, Carbohydrate-based Drug Discovery (Ed.: C.-H. Wong), Wiley-VCH, Weinheim, 2003, 1, 281-301.

[2] J. Schweden, C. Borgmann, G. Legler, E. Bause, Arch. Biochem. Biophys. 1986, $248,335-340$.

[3] N. Sharon, H. Lis, Sci. Am. 1993, 268, 82-89.

[4] a) P. Hollander, X. Pi-Sunyer, R. E. Conif, Diabetes Care 1997, 20, 248-253; b) A. Mitrakou, N. Tountas, A. E. Raptis, R. J. Bauer, H. Shulz, S. A. Raptis, Diabet. Med. 1998, 15, 657-660; c) L. Scott, C. M. Spencer, Drugs 2000, 59, 521-549; d) A. Y. Y. Cheng, R. G. Josse, Drug Discov. Today 2004, 201-206.

[5] C. P. Kordik, A. B. Reitz, J. Med. Chem. 1999, 42, 181-201.

[6] a) F. M. Platt, T. D. Butters, Exp. Rev. Mol. Med. 2000, 1-18; b) T. D. Butters, R. A. Dwek, F. M. Platt, Curr. Top. Med. Chem. 2003, 3, 561-574; c) M. Takeuchi, K. Kamata, M. Yoshida, Y. Kameda, K. Matsui, J. Biochem. 1990, 108, 42-46; d) T. D. Butters, R. A. Dwek, F. M. Platt, Glycobiology 2005, 15, 43R-52R.

[7] a) M. J. Papandreou, R. Barbouche, R. Guieu, M. P. Kieny, E. Fenouillet, Mol. Pharmacol. 2002, 61, 186- 193; b) P. S. Sunkara, D. L. Taylor, M. S. Kang, T. L. Bowlin, P. S. Liu, A. S. Tyms, A. Sjoerdsma, Lancet 1989, 333, 1206; c) M. Dettenhofer, X.-F. Yu, J. Biol. Chem. 2001, 276, 5985-5991; d) G. S. Jacob, Curr. Opin. Struct. Biol. 1995, 5, 605-611.

[8] a) N. Asano, A. Kato, A. A. Watson, Mini Rev. Med. Chem. 2001, 1, 145-154; b) B. Ganem, Acc. Chem. Res. 1996, 29, 340-347; c) N. Asano, Glycobiology 2003, 13, 
93R-104R; d) Y. Nishimura, Curr. Top. Med. Chem. 2003, 3, 575-591; e) T. A. Houston, J. T. Blanchfield, Mini Rev. Med. Chem. 2003, 3, 669-678.

[9] E. B. Melo, A. S. Gomes, I. Carvalho, Tetrahedron 2006, 62, 10277-10302.

[10] A. Takatsuki, M. Nakajima, O. Ando, Jpn Kokai Tokkyo Kohou, 96134091 (May 28, 1996).

[11] a) M. Shiozaki, Tetrahedron: Asymmetry 1999, 10, 1477-1482; b) Y. Watanabe, M. Shiozaki, R. Kamegai, Carbohydr. Res. 2001, 335, 283-289.

[12] M. Li, X. Han, B. Yu, J. Org. Chem. 2003, 68, 6842-6845.

[13] M. K. Gurjar, L. K. Reddy, S. Hotha, J. Org. Chem. 2001, 66, 4657-4660.

[14] L. V. Backinowsky, S. A. Nepogod'ev, A. S. Shashkov, N. K. Kochetkov, Carbohydr. Res. 1985, 138, 41-54.

[15] I. Chiu-Machado, J. C. Castro-Palomino, O. Madrazo-Alonso, C. Lopetegui-Palacios, V. Verez-Bencomo, J. Carbohydr. Chem. 1995, 14, 551-561.

[16] M. Wilstermann, G. Magnusson, J. Org. Chem. 1997, 62, 7961-7971.

[17] 2,3,5-Tri-O-acetyl-D-xylofuranosyl trichloroacetimidates (6) was prepared by condensation of 2,3,5-tri-O-acetyl-D-xylofuranose (W. J. Hennen, H. M. Sweers, Y. Wang, C.-H. Wong, J. Org. Chem. 1988, 53, 4939-4945) with $\mathrm{CCl}_{3} \mathrm{CN}$ in the presence of DBU in $\mathrm{CH}_{2} \mathrm{Cl}_{2}(88 \%)$.

[18] (a) N. Miyaura, A. Suzuki, Chem. Rev. 1995, 95, 2457-2483. (b) N. Miyaura, Top. Curr. Chem. 2002, 219, 11-59.

[19] H. S. Rho, B.-S. Ko, Y.-S. Ju, Synth. Commun. 2001, 31, 2101-2106.

[20] a) D. Zembower, H. Zhang, J. Org. Chem. 1998, 63, 9300-9305; b) X. Zheng, W. Meng, F. Qing, Tetrahedron Lett. 2004, 45, 8083-8085; c) X. Huang, E. Tang, W. M. Xu, J. Cao, J. Comb. Chem. 2005, 7, 802-805; d) W. Peng, X. Han, B. Yu, Chin. J. Chem. 2006, 24, 1154-1162. 
[21] S. D. Walker, T. E. Barder, J. R. Martinelli, S. L. Buchwald, Angew. Chem. Int. Ed. 2004, 43, 1871-1876. 